\title{
Geographical, Biological and Remote Sensing Aspects of the Hydrologic Atmospheric Pilot Experiment in the Sahel (HAPEX-Sahel)
}

\author{
S. D. Prince, ${ }^{1}$ Y. H. Kerr, ${ }^{2}$ J.-P. Goutorbe, ${ }^{3}$ T. Lebel, ${ }^{4}$ A. Tinga, ${ }^{5}$ \\ P. Bessemoulin, ${ }^{6}$ J. Brouwer, ${ }^{7}$ A. J. Dolman, ${ }^{8}$ E. T. Engman, ${ }^{9}$ \\ J. H. C. Gash, ${ }^{10}$ M. Hoepffner, ${ }^{11}$ P. Kabat, ${ }^{8}$ B. Monteny, ${ }^{11}$ F. Said ${ }^{12}$ \\ P. Sellers, ${ }^{13}$ and J. Wallace ${ }^{10}$
}

\begin{abstract}
$H$ ment in the Sahel) was an international program focused on the soil-plant-atmosphere energy, water and carbon balance in the west African Sahel. It was intended to improve our understanding of the interaction between the Sahel and the general atmospheric circulation, both at present and in the future, providing a base line for studies of climate change. It was carried out in $a 1^{\circ} \times 1^{\circ}$ area of west Niger over a 3-4 year period with an 8-week intensive observation period from August to October 1992. HAPEX-Sahel was funded by a wide range of agencies in seven participating countries. Over 170 scientists visited and worked in the field. An interdisciplinary approach was adopted with contributed studies in hydrology and soil moisture, surface fluxes and vegetation,
\end{abstract} Park

${ }^{1}$ Department of Geography, University of Maryland, College

${ }^{2}$ LERTS, Toulouse, France

${ }^{3}$ CNRM / GMME, Toulouse, France

${ }^{4}$ ORSTOM, Niamey, Niger

${ }^{5}$ Université de Niamey, Niamey, Niger

${ }^{6}$ CNRM / GMET, Toulouse, France

${ }^{7}$ Department of Soil Science and Geology, Wageningen, The Netherlands and ICRISAT, BP 12404, Niamey, Niger

${ }^{8}$ Winand Staring Centre, (SC-DLO), Wageningen, The Netherlands

${ }^{9}$ Hydrological Sciences Branch, NASA Goddard Space Flight Center, Greenbelt, MD

${ }^{10}$ Institute of Hydrology, Wallingford, UK

${ }^{11}$ ORSTOM, Montpellier, France

${ }^{12}$ UPS Laboratoire d'Aerologie, Toulouse, France

${ }^{13}$ Biospheric Sciences Branch, NASA Goddard Space Flight Center, Greenbelt, MD

Address correspondence to S. D. Prince, Room 1113 Lefrak Hall, Department of Geography, University of Maryland, College Park, MD 20742-8225.

Received 6 August 1993; accepted 16 February 1994. remote sensing science, and meteorology and mesoscale modeling. Detailed field measurements were concentrated at 3 "supersites" and 3 ancillary sites. Four aircraft were used for remote sensing and flux measurement. Observations from space were acquired from nine sensors on seven different satellite platforms. Conditions in 1992 turned out to be average for the last decade with good gradients of precipitation and a variety of vegetation productivities between the study sites. An information system has been established to provide a data base to disseminate the measurements. An active program of meetings, workshops, and interdisciplinary studies is now in progress.

\section{INTRODUCTION}

HAPEX-Sahel (Hydrologic and Atmospheric Pilot Experiment in the Sahel) was an international program of land surface-atmosphere observations undertaken in west Niger, in the West African Sahel region. The overall aims were to improve our understanding of the effect of the Sahel on the general atmospheric circulation, in particular the responses of the circulation to the large interannual fluctuations of land surface conditions in this region. In turn ideas could be developed about how the general circulation is related to the persistent droughts that have affected the Sahel during the last 25 years: During the field program measurements were obtained of atmospheric, surface, and certain subsurface processes in a $1^{\circ} \times 1^{\circ}$ area (approximately $110 \times 110$ $\mathrm{km}$ ) that incorporates examples of many of the major land surface types found throughout the Sahel. An important consideration was that the data should be applicable to the resolution scales of current general circula-

REMOTE SENS. ENVIRON, 51:215-234 (1995) 
tion models (GCM). In order to obtain data for this large area, an extensive measurement program was undertaken including field, aircraft, and satellite remote sensing measurements, mainly between mid-1990 and late 1993. An intensive operation period (IOP) was undertaken for 8 weeks from the mid to late growing season of 1992.

HAPEX-Sahel was initiated in response to the World Climate Research Programme (WCRP) Global Energy and Water Cycles Experiment (GEWEX). This experiment aims to determine the fluxes of water and energy globally in order to quantify the energetic processes of the Earth's climate system and the forcing functions on the ocean, land, ice, and vegetation. GEWEX recognizes the need for more realistic measurements of major global environments, especially criti$\mathrm{cal}$ areas that are thought to have strong influences on the general circulation. The Sahel forms the border of the Sahara desert, which is a major source of sensible heat for the atmosphere. Any extension or reduction of desert-like conditions due to fluctuations in the rainfall and vegetation of the Sahel are therefore likely to have strong feedbacks on the general circulation through the energy balance and other processes (Charney, 1975; Xue and Shukla, 1993).

HAPEX-Sahel is also relevant to the International Geosphere-Biosphere Programme (IGBP). This is an evolving international program that aims to understand the interactive physical, chemical, and biological processes that regulate the global environment and the changes that are taking place in the biosphere. Several IGBP core projects are expected to benefit from HAPEXSahel, including the International Global Atmospheric Chemistry Project (IGAC), Biospheric Aspects of the Hydrological Cycle (BAHC), Global Change and Terrestrial Ecosystems (GCTE), and Global Analysis, Interpretation and Modeling (GAIM). In addition the French IGBP program, Savannas on the Long Term (SALT), has designated the HAPEX-Sahel site as one of its study areas.

The approach adopted in HAPEX-Sahel was similar to that of HAPEX MOBILHY in SW France (André et al., 1988), the First ISLSCP Field Experiment (FIFE) in tallgrass prairie in Kansas, USA (Sellers et al., 1988), and the European Field Experiment in Desertification threatened Areas (EFEDA) in Spain (Bolle et al., 1993). As in these earlier campaigns, the aim was to make simultaneous measurements of relevant variables at a number of scales, but with a notable increase in HAPEXSahel to an area of $110 \times 110 \mathrm{~km}^{2}$. In the case of fluxes of water vapor, for instance, measurements were made at the leaf, canopy, stand, landscape, and $1^{\circ} \times 1^{\circ}$ scales, using porometers, eddy correlation fluxes from towers and aircraft, radiosondes and tethered balloons. Similar designs were adopted for all aspects of the energy, water, and carbon balances. Aircraft and satellite remote sensing was undertaken to extend the measurements to the $1^{\circ} \times 1^{\circ}$ square.

HAPEX-Sahel faced several particular challenges. The heterogeneity of surface types and seasonal variations in the region are much greater than in the areas studied in any previous measurement campaign of this type. HAPEX-Sahel is also the first activity of this sort to be undertaken in extreme conditions of heat, dust, and solar radiation. As such it has provided a valuable opportunity to test our ability to operate a wide variety of sophisticated techniques far from home laboratories and thus to assess our capability of mounting similar campaigns in other remote parts of the world.

\section{THE SAHEL AND THE STUDY AREA}

\section{The Sahelian Environment}

The Sahel is an Arabic word that means the shore or boundary. It occupies a narrow zone between the Sahara to the north and the Sudanian vegetation zone to the south (White, 1983). It forms a strip about $400-600 \mathrm{~km}$ from north to south, $3 \times 10^{6} \mathrm{~km}^{2}$ in area, that stretches nearly $6,000 \mathrm{~km}$ across the entire African continent (Le Houérou, 1989).

The region is characterized by a single, short, annual rainy season associated with the northward movement of the Inter Tropical Convergence Zone (ITCZ). The ITCZ is the junction of the dry, mid-continental air mass and humid, maritime air from the Atlantic that forms the ascending branch of the Hadley cell. Dry, dust-laden, cooler air from the northeast is undercut by a wedge of warm, humid air from the Gulf of Guinea. Disturbances develop between the two air masses and give rise to storms. Storms often occur in squall lines caused by organized, easterly waves that propagate from east to west between the Tropical Easterly and the African Easterly Jets (Farmer, 1989). In addition local convective storms are common. The locations of storms are unpredictable and they typically cover only $1 \%-$ $10 \%$ of the region at any one time. Thus rainfall is highly variable in time and space, as in other semi-arid regions of the world. As the "thermal equator," the ITCZ migrates north and south with the apparent movement of the sun so that rainfall decreases from south to north in the Sahel (Leroux, 1983). In fact the boundaries of the Sahel are generally defined with reference to the rainfall gradient. The 100 or $150 \mathrm{~mm}$ isohyet is often used to designate the northern boundary and somewhere between the $600-800 \mathrm{~mm}$ isohyets defines the southern boundary (Le Houérou, 1989).

The landscape of the Sahel is generally flat or gently undulating at altitudes below $600 \mathrm{~m}$. Only two mountainous regions are found in the Sahel proper (in Western Sudan). Large areas are covered with Pleistocene, aeolean sand sheets, particularly in the north, but also 
in parts of the south Sahel. Fossil dunes formed in the sand sheets create an undulating relief with $2-3 \mathrm{~km}$ between dune crests. The sand is vegetated and active dunes only occur locally in response to disturbance. Clay plains and alluvial flood plains, valleys without flowing water (wadis and dalols), pediplains, and plateaux are occasional geomorphological features. Much of the nonsand sheet area is coated with a sand veil of varying thickness from a few centimeters to several meters (Le Houérou, 1989).

The current drainage systems in the Sahel were mostly developed during the wetter Pleistocene periods and are now not active. Virtually all drainage is endoreic and surface flow rarely occurs over more than a few hundred meters. Pools form during the rainy season and the water gradually evaporates or infiltrates between rain events, drying completely soon after the rains. Stream-flow methods to estimate runoff are thus not applicable at a catchment scale in much of the region. The major rivers of the Sahel, the Niger, Senegal and Nile, mainly carry water that comes from outside the region and not from Sahelian rainfall.

The vegetation of the Sahel consists of annual grass and scattered bush steppe in the north, gradually merging into Sudanian savannas with perennial grasses, scattered trees, and extensive rain-fed cultivation in the south (White, 1983). The vegetation is strongly seasonal; virtually all woody species are deciduous, whereas all herbs are either annual or die back to the ground each dry season. In the north herbs are green for approximately 1 month, increasing to 3 months in the south. Potential evapotranspiration is generally about $2000 \mathrm{~mm}$ and so the actual evapotranspiration and plant production is a function of the rainfall and its distribution in the season.

The Sahel is extensively utilized by humans, however, intensive inputs such as artificial fertilizers, fencing, and irrigation are rare. Traditionally the Sahel was a pastoral zone with nomadic and transhumant herding in the north and more settled mixed herding and agriculture in the south, but the population of the Sahel has more than doubled in the last 40 years (van den Oever, 1989) and for this reason and also perhaps because of economic changes (Franke and Chasin, 1992) sedentary agriculture has moved into much of the central Sahel that was previously regarded as unsuitable. Thus much of the landscape of the southern and more favorable mid-Sahel consists of fields and extensive areas of fallow bush-grassland in various stages of regrowth. Moreover the changes in recent years have led to a decrease in the length of the fallow period.

The staple crops of the Sahel vary with rainfall and to some extent between countries. Millet (Pennisetum glauca) is most widely planted in Niger but in wetter areas some sorghum. (Sorghum bicolor) and corn (Zea mays) is grown. Rice is only found in irrigated areas

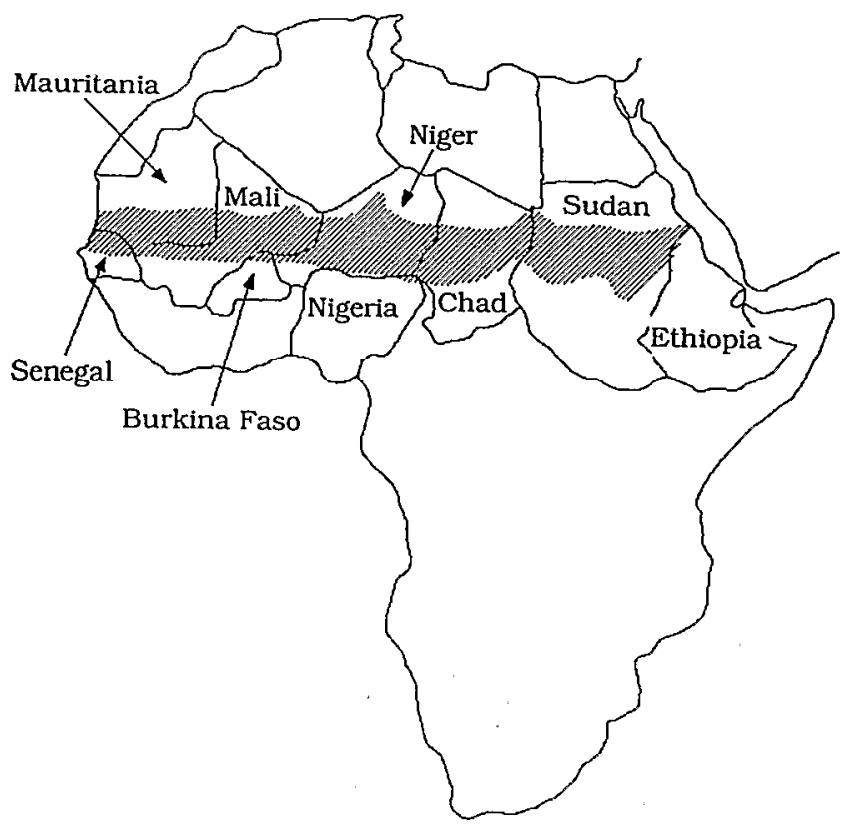

Figure 1. Map of Africa showing the Sahel zone and the location of the HAPEX-Sahel experiment (map modified from Le Houérou, 1989).

bordering the main rivers. Cowpea (Vigna unguiculata) is commonly intercropped with millet. Other crops include groundnuts (Arachis hypogea) and hibiscus (Hibiscus sabdariffa) (Le Houérou, 1989).

\section{The HAPEX-Sahel Study Site}

A $1^{\circ} \times 1^{\circ}$ region (approximately $110 \times 110 \mathrm{~km}^{2}$ ) was selected in which regional measurements were made

Figure 2. The HAPEX-Sahel $1^{\circ} \times 1^{\circ}$ square in western $\mathrm{Ni}$ ger, the three super sites, East Central (EC), West Central (WC), and Southern (SS), and three ancillary sites Danguey Gorou (DG), Hamdallay (H), and Gourmanday in the Dalol Bosso (DB).

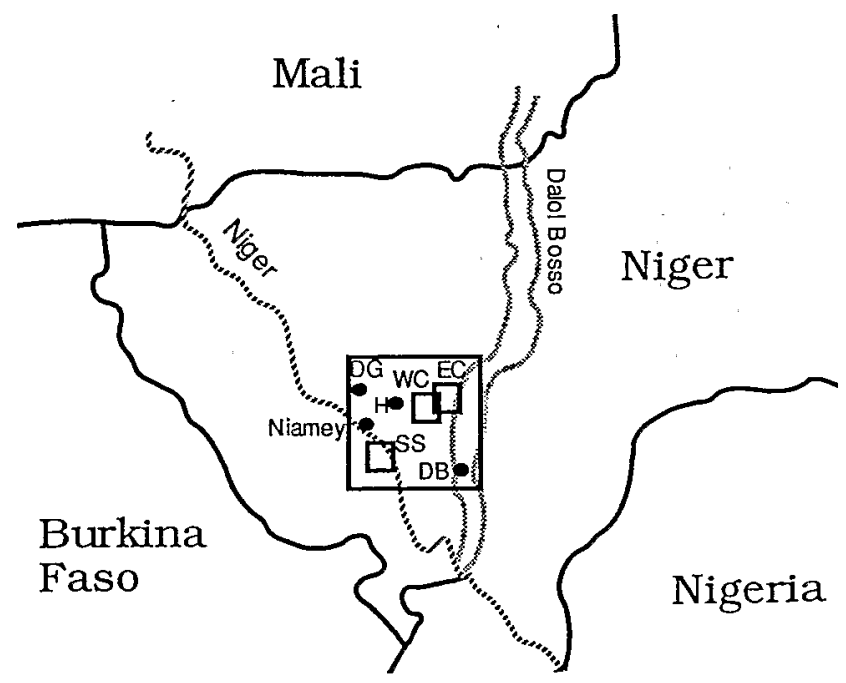




\section{HAPEX}

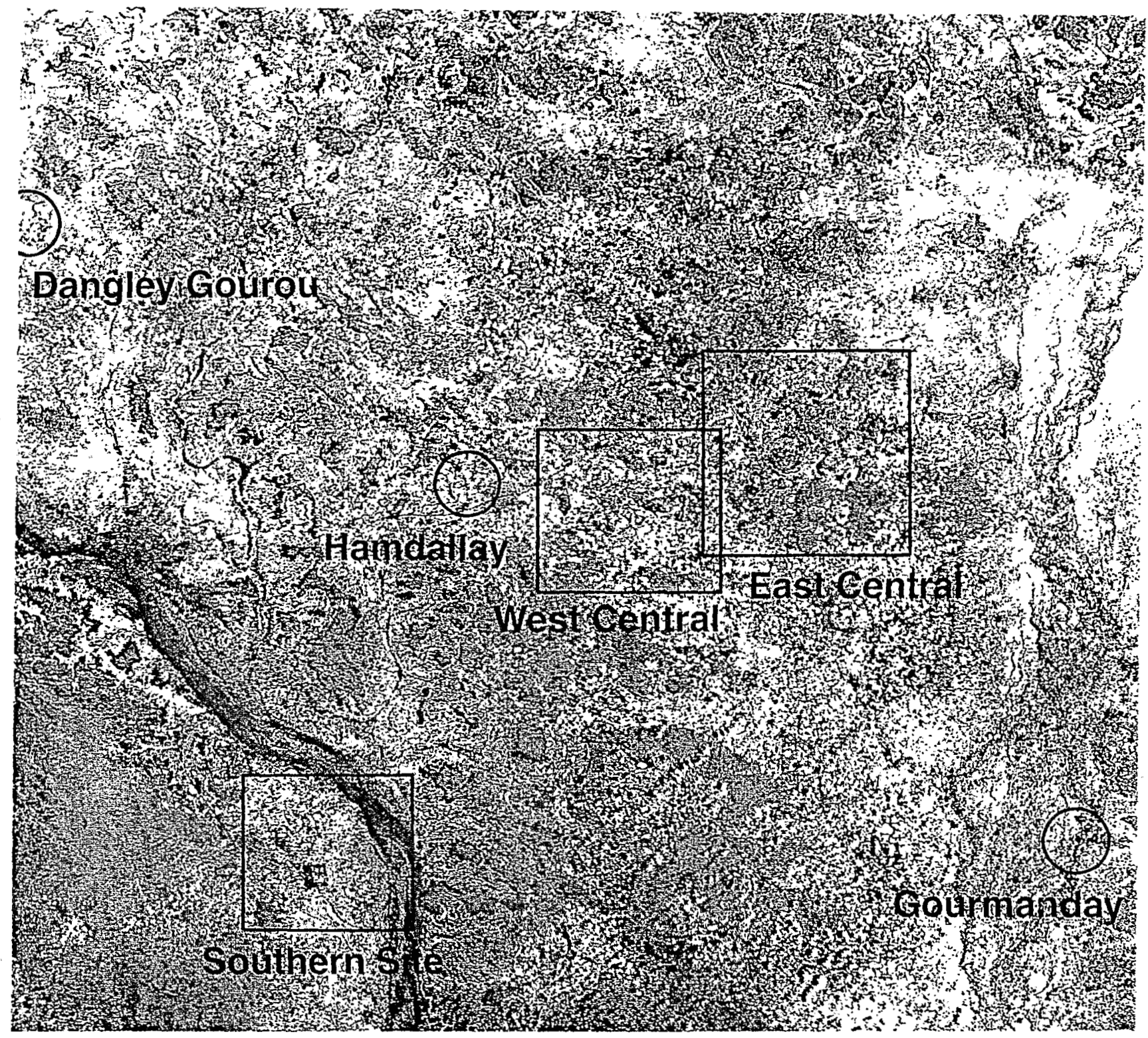

Figure 3. A false color composite mosaic of four Landsat TM images acquired on 18 (eastern two scenes) and 25 (western two scenes) September 1992 showing the HAPEX-Sahel $1^{\circ} \times 1^{\circ}$ square. Red-channel 4 near infrared $(0.76-0.90 \mu \mathrm{m})$, green-channel 5 mid-infrared $(1.55-1.75 \mu \mathrm{m})$, blue-channel 3 red $(0.63-0.69 \mu \mathrm{m})$. Green vegetation appears red. The plateaus with tiger bush appear green with red stripes of tiger bush. The sand-filled valleys have a patchwork of darker areas (fallow) and brighter areas (millet crops). Note some altocumulus cloud in the south east corner of the square. The three supersites and three ancillary sites are labeled.

and within which three supersites were located for detailed measurements. The $2^{\circ}-3^{\circ} \mathrm{E}, 13^{\circ}-14^{\circ} \mathrm{N}$ square that contains Niamey was chosen (Figure 2). The Niger river flows across the SW quadrant of the square and the Dalol Bosso valley forms the eastern margin (Figure 2). Within these bounds the landscape is a dissected plateau of Tertiary, Continental Terminal, fluvio-lacustrine deposits capped by a thick, ferruginous duricrust or laterite layer formed in the Quaternary. Up to three or four laterite layers are found at various depths buried by subsequent Tertiary and Quaternary deposits. The plateaux form isolated mesas with steep edges rising 30 
to $60 \mathrm{~m}$ above the sand-filled valleys. Over the Continental Terminal are the remains of linear Pleistocene sand dunes. At the latitude of the study area the exact boundaries of these dunes are difficult to detect, but they seem to be up to $10 \mathrm{~km}$ in width with the same $100^{\circ}-$ $280^{\circ}$ alignment as the intact dunes to the north of the study area. All these features are shown in the satellite image of the study area (Figure 3).

The climate of the study area is typical of the southern Sahel. Mean rainfall at Niamey is about 560 nm (1905-1989) with a north to south gradient of about $1 \mathrm{~mm} \mathrm{~km}{ }^{-1}$ (Lebel et al., 1992). The last 25 years have been marked with persistent low rainfall and the mean for this period is $495 \mathrm{~mm}$ (Figure 4). The average length of the growing season at Niamey is 94 days (Sivakumar, 1989). Potential evapotranspiration is about $2000 \mathrm{~mm}$ and the annual deficit between evapotranspiration and rainfall increases northward by about $200 \mathrm{~mm}$ per degree of latitude (Sivakumar, 1989). Winds are strongly linked to the seasons. During the dry season the Harmat$\tan$ blows from the desert area to the north east and during the rainy season humid winds blow from the south west. Wind speeds can be very high for short periods associated with violent thunderstorms and squall lines. Dust storms often precede thunderstorms and enormous amounts of dust from the bare, loose sandy soils are carried in the air and partially redeposited in the subsequent rain. Mean of minimum and maximum temperatures in the Sudano-Sahelian region for the rainy season are $22^{\circ}$ and $34^{\circ} \mathrm{C}$, respectively, increasing northwards (Sivakumar, 1989).

No one $1^{\circ} \times 1^{\circ}$ area could contain all the landscape components of the Sahel and the proportions of the components that are included in the HAPEX study area are not entirely typical of the whole subcontinental region. Nevertheless the study area does not contain a

Figure 4. Rainfall in the HAPEX-Sahel study area. Standardized rainfall departures for $10^{\circ}-15^{\circ} \mathrm{N}, 0^{\circ}-5^{\circ} \mathrm{E}$ from 1905 to 1990. Standardized departure $=\left(100 \sum_{i=1}^{n}\left(P_{i}-\bar{P}_{i}\right) / s_{i}\right) n^{-1}$. Where $P_{i}, \bar{P}_{i}, s_{i}$ are the annual rainfall, long-term mean rainfall and long term standard deviation of rainfall at station $i$. $n$ is the number of stations (up to 13) (data supplied by S. Nicholson, Florida State University).

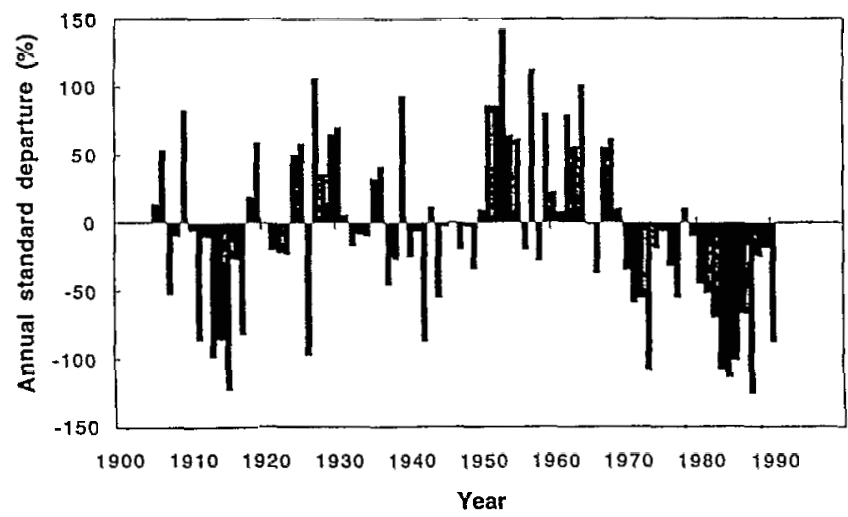

wider range of landscape elements than most areas of the Sahel and reasonable examples of the more widespread surfaces can be found in the area, with the exception of extensive annual grassland on sand sheets, and clay plains.

The landscape in the $1^{\circ} \times 1^{\circ}$ region consists of repeated toposequences from plateaux to valley bottoms (Figure 5). On the plateaux 0.1-0.5 m of gravely sand or gravely loam overlies the laterite, with solid laterite starting at $0.2-0.9 \mathrm{~m}$ depth. Vegetation arcs occur consisting of 3-5 m tall, 10-m wide stripes of varying length with their long axis aligned across the very slight slopes that dip towards the plateau edge. Between adjacent stripes there is generally no soil or vegetation. The resulting landscape has the appearance from the air of a tiger's coat, hence the term "tiger bush" (White, 1971; Ambouta, 1984). In some areas sand lenses occur on the plateaux that have vegetation indistinguishable from the sand-filled valleys. Other laterite layers are found below the valley sands at varying depths at least in some areas. Often laterites are exposed and form narrow or extensive shelves in the toposequence. Plateaux form about $20 \%$ of the region of which about one-third is sand covered and is mostly under millet (Table 1). The edges of the plateaux can be abrupt with a steep escarpment of outcrops of ironstone falling $10-20 \mathrm{~m}$ to a sloping sand skirt heaped up against the plateau by runoff and wind action. Alternatively, the plateaux may end in a more gentle transition to the aeolian sands that fill the valleys. Typically these upper sands are red in color. The sand skirt, where present, has a steep slope and is drained by parallel gullies filled with bushes. Little vegetation occurs between the gullies on the upper slopes, but millet cultivation is common on the lower slopes. The sand skirt gives way to an undulating sandy, or sandy loam valley floor covered with millet fields and fallow, and finally a valley bottom with deep

Figure 5. Schematic section of a typical toposequence in the HAPEX-Sahel study area showing vegetation, slopes, and soil characteristics (partly based on Wilding and Hossner, 1989; Epema and Oevelen, 1993; Legger, 1993)

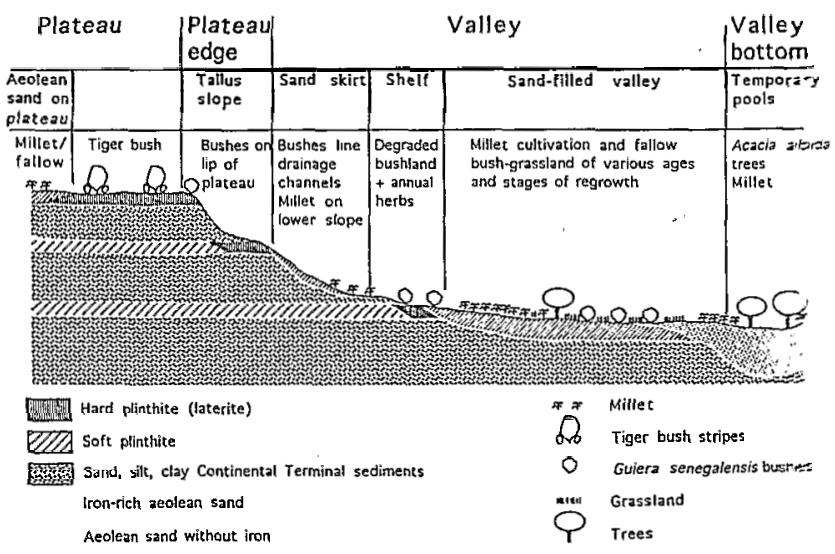


Table 1. The legend to the Spatio-Carte des États de Surface du Sol du Degré Carré de Niamey (Courault et al. 1992), showing the principal land surface types in the $1^{\circ} \times 1^{\circ}$ HAPEX-II-Sahel study area in Niger

\begin{tabular}{|c|c|c|c|c|}
\hline $\begin{array}{c}\text { Dominant } \\
\text { Characteristic }\end{array}$ & $\begin{array}{l}\text { Vegetation } \\
\text { Cover }\end{array}$ & $\begin{array}{c}\text { Dominant } \\
\text { Soil Crust } \\
\text { Type }(s)^{a}\end{array}$ & $\begin{array}{c}\text { Principal } \\
\text { Land Use(s) }\end{array}$ & $\begin{array}{l}\text { Area } \\
\left(\mathrm{km}^{2}\right)\end{array}$ \\
\hline Plateau & None & $\begin{array}{c}\text { grossière } \\
\text { érosion }\end{array}$ & None & 551 \\
\hline Plateau & None & $\begin{array}{l}\text { grossière } \\
\text { décantation }\end{array}$ & None & 931 \\
\hline $\begin{array}{l}\text { Sand covered } \\
\text { plateau }\end{array}$ & None-low & érosion & $\begin{array}{l}\text { Agro-sylvo- } \\
\text { pastoral }\end{array}$ & 910 \\
\hline Plateau edge & None-low & érosion & Sylvo-pastoral & 163 \\
\hline Aeolian sand & Medium-dense & - & Fallow & 638 \\
\hline Aeolian sand & None-medium & structurale & Agro-pastoral & 1,870 \\
\hline Aeolian sand & None-low & érosion & Agriculture & 1,572 \\
\hline $\begin{array}{l}\text { Valley bottoms, } \\
\text {.sandy plains }\end{array}$ & None-medium & - & Agro-pastoral & 2,370 \\
\hline Azonal & - & $\begin{array}{c}\text { érosion } \\
\text { bâti }\end{array}$ & $\begin{array}{l}\text { Agriculture } \\
\text { and urban }\end{array}$ & 1,293 \\
\hline Azonal & Dense & - & Forest and rice & 710 \\
\hline Azonal & Low-medium & $\begin{array}{l}\text { érosion, } \\
\text { structurale }\end{array}$ & Agro-pastoral & 893 \\
\hline Open water & - & - & - & 62 \\
\hline Unclassified & - & - & - & 5 \\
\hline
\end{tabular}

a Soil crustal characteristics follow Casenave and Valentin (1989).

sands that may have temporary pools during the rainy season. The Niger river valley varies in width. It contains extensive areas of clayey sediments, many of which are used for irrigated rice growing. The Dalol Bosso, at the eastern edge of the HAPEX square, is a sand-filled valley with an undulating surface and some areas of persistent pools during the rainy season. Many valleys of this sort, that now have no flowing water, were formed during periods of higher rainfall, most recently 5,000 BP. The Dalol Bosso is intensively cultivated and, where extensive pools occur, sometimes there are small rice paddies.

The valley floor vegetation consists of a fine-grained patchwork of cover types, mainly millet fields and various ages of fallow. Approximately $57 \%$ of the area is under millet cultivation and $22 \%$ is fallow (Table 1 ). This pattern presented a particular challenge and constraint to the selection of study sites. For certain types of measurements, such as surface fluxes, there is a minimum site size that is dictated by factors such as the roughness of the vegetation. Airborne measurements are also difficult in this type of terrain when the field of view of the sensor is about the size of the landscape units because it is difficult to obtain pure fields of view, uncontaminated by neighboring cover types.

\section{Field Sites}

A three-level hierarchy of sites was established in order to sample the study area and to provide the appropriate size and uniformity of sites needed for each of the wide variety of measurement techniques that were used in
HAPEX-Sahel. First, one $1^{\circ} \times 1^{\circ}$ square was selected as already explained; second, three supersites were identified inside the $1^{\circ} \times 1^{\circ}$ square, each approximately $20 \times 20 \mathrm{~km}^{2}$ (Figure 2); third, within each supersite, three or more subsites were selected, one in each of the principal landscape components of the supersite. Below the level of the subsite, two further, less formalized, subdivisions were used. First, the subsites were themselves divided into a number of stands, one of which was generally used for flux measurements, and the others for other types of measurements needed to analyze the fluxes. Second, below the stand level, some studies employed individual plants or specific soil sampling locations. This sampling structure was intended to assist in the subsequent scaling of field measurements to the landscape and regional scales.

At the scale of the $1^{\circ} \times 1^{\circ}$ square there were extensive measurements of rainfall both by approximately 110 automatic raingauges and a rainfall radar and also data were collected by a network of 12 automatic meteorological stations. Vegetation and soil surface features were mapped and groundwater levels were monitored in a network of wells.

The selection of the precise location of the supersites was determined by the particular needs of the types of measurements that were planned. The southern and central west sites were intended primarily for surface flux and energy balance studies and this demanded stands large enough to measure the fluxes associated with the surface type within the stand, without significant influences from surrounding surface types. The 


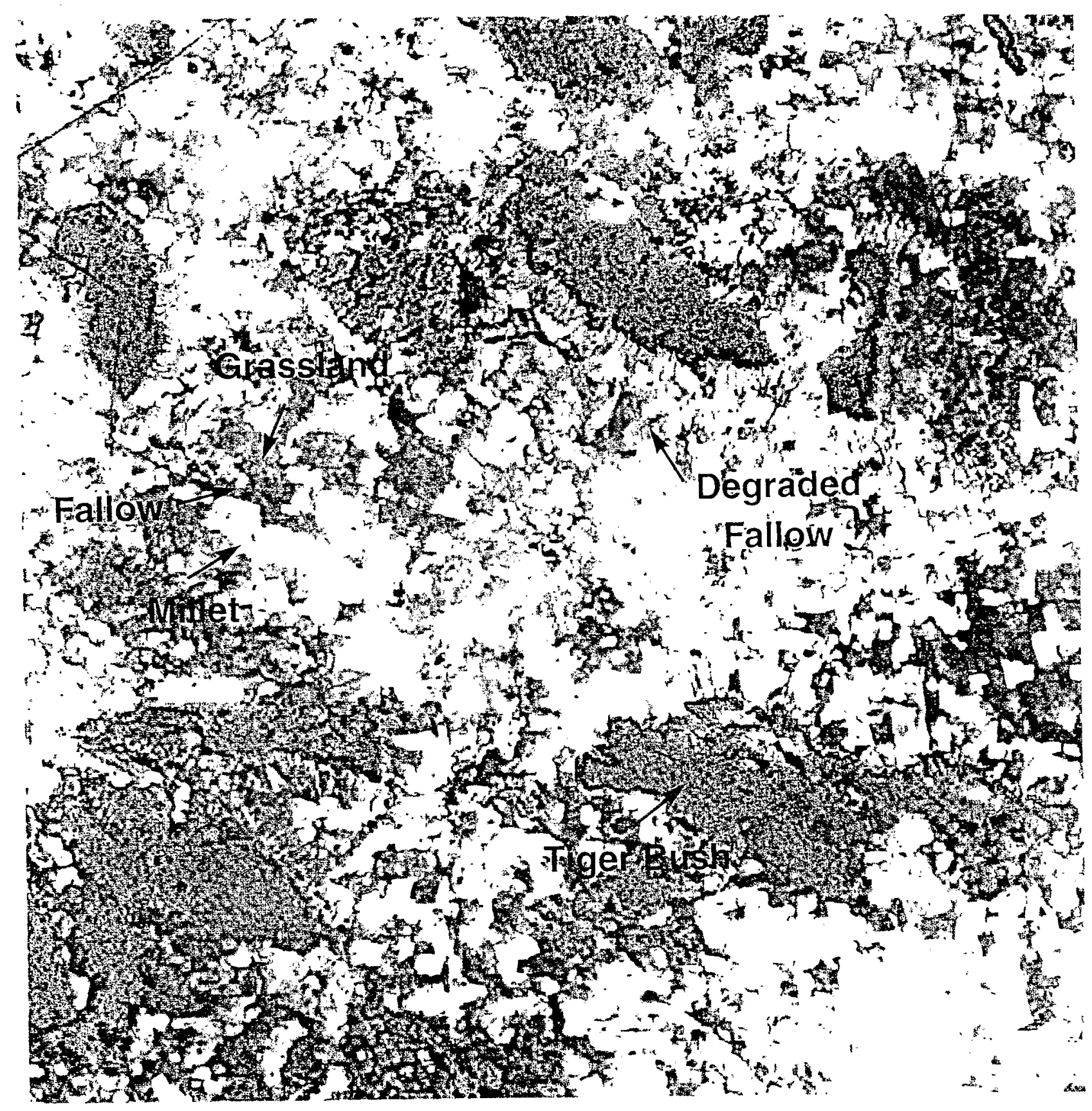

Figure 6. An enlargement of the Landsat T.M mosaic in Figure 3 showing the West Central anpersite. The five subsitcs. fal low grassland, fallow bush-grassland, millet crop, tiger bush, and degraded bush fallow are laheled.

central east supersite was selected primarily as a catchment for hydrological studies.

The supersites were not expected to capture the north-sonth gratient of rainfall because manfall is spattially very variable at the scale of a $1^{\circ} \times 1^{\circ}$ square and the north-sonth gradient of rainfall is a phenomenom that is observed either at the scale of the contire Sahed ar locally only in the long-term arerage ranfall. Nevertheless, in 1992, the east central site received albout half the rainfall of the southern site.

Three principal surface cover types were selected as subsites at each supersite: tierer bush on the plateans fallow bush-grasstand on the valley sands, and mille. fields. Each sulusite was plated in all cextensive area wa the relevant corer lype (ligure 6 ).

Three ancillary sites were instrumented to improme the surface flus comerage of the $1^{\circ} \times 1^{\circ}$ seguare (foigur 2. First, a flux lomer wats estahlished in extensive mille. fielels at Danguey (iorou in the northwest of the $1^{\circ} \times 1$ : sefuate. Second, a tedhered hallown was flown oceasione alls. coordinated with Merlin werflights. at Coumamdey in the south east comere of the $1^{\circ} \times 1^{\circ}$ sequare it. 

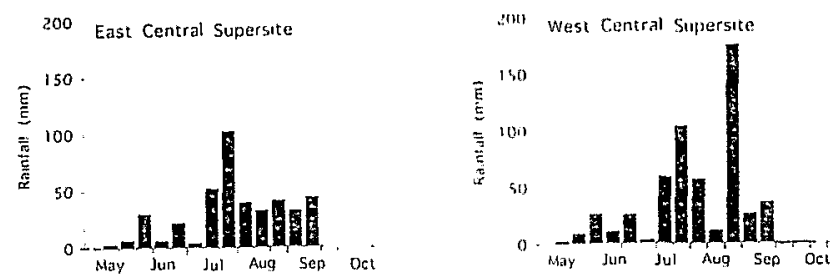

200 Southern Supersite
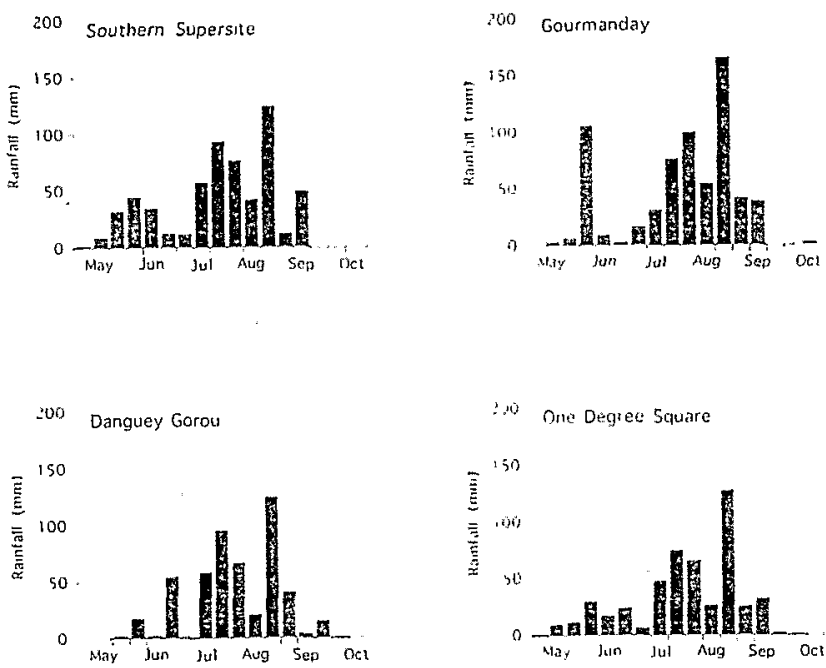

Figure 7. Decadal rainfall recorded in each HAPEX-Sahel supersite and ancillary site in 1992. The supersite rainfall is for each entire $20 \times 20 \mathrm{~km}$ or $15 \times 15 \mathrm{~km}$ site, and is derived from the kriged surface for the whole $1^{\circ} \times 1^{\circ}$ square, obtained from the EPSAT-Niger raingauge network measurements for the 1992 rainy season. The ancillary site values are for the nearest raingauge (missing periods replaced with the next nearest rainfall station values) (Taupin et al., 1993).

the Dalol Bosso. Both sites were used for radiosonde releases. Third, an intensive radiosounding station was set up at Hamdallay close to the center of the area in order to document, among other phenomena, the temporal evolution of the structure of the atmospheric boundary layer. Radiosoundings at Hamdallay were carried out every 2 hours and were coordinated with airborne flux measurements and tethered balloon ascents.

\section{Conditions During the 1992 Field Campaign}

The main feature of the 1992 rainfall was the early start of the rains followed by a dry spell from early June

Table 2. Rainfall Recorded in EPSAT Giuges within Each HAPEX Super-site in 1992 (after Taupin tet al., 1993)

\begin{tabular}{lcccc}
\hline Super-site & $\begin{array}{c}\text { Maximum } \\
\text { mm }\end{array}$ & $\begin{array}{c}\text { Minimum } \\
m m\end{array}$ & $\begin{array}{c}\text { Total } \\
m m\end{array}$ & $\begin{array}{c}\text { Number of } \\
\text { Gauges }\end{array}$ \\
\hline East Central & 591 & 410 & +21 & 17 \\
West Central & 553 & 446 & 554 & 9 \\
Southern & 782 & 507 & $60: 3$ & 5 \\
\hline
\end{tabular}

Total rainfall is the sum of the kriged surfaces of deceatal rainfall for each super site.

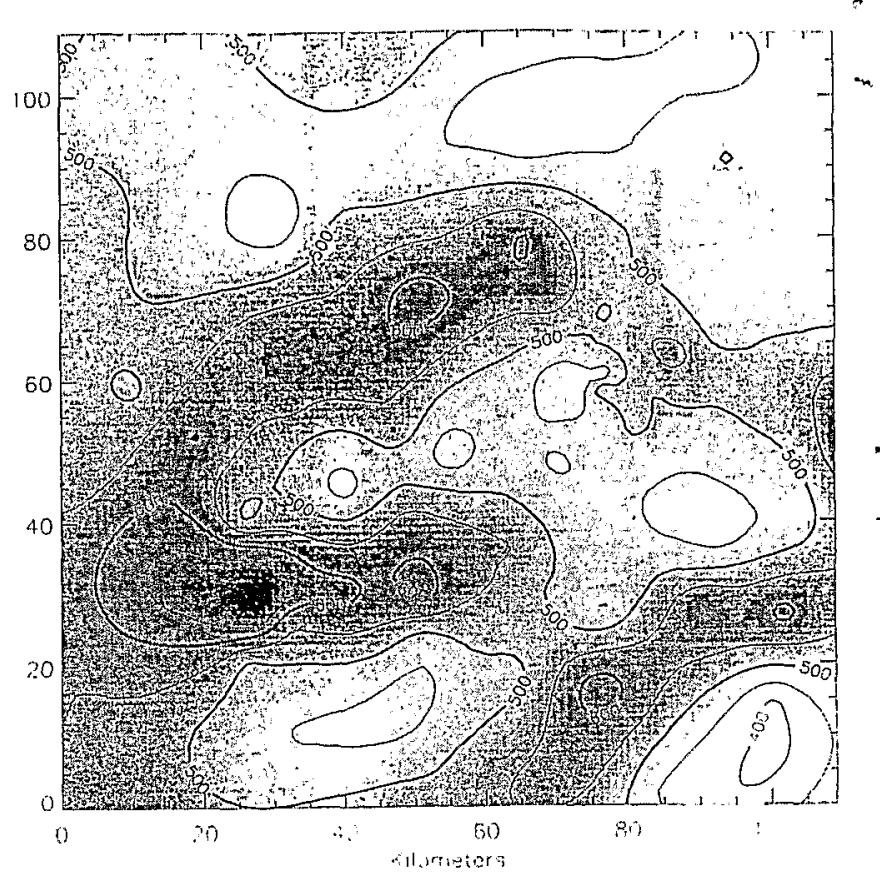

Figure 8. Spatial distribution of rainfall over the HAPL.XSahel square in 1992. The seasonal kriged surface of EPSAT-Niger data (Taupin et al., 1993).

until mid-July. Following the break, rainfall was abowe average in August and early September (Figure 7 ). The maximum, minimum, and mean rainfall recorded by rain gauges distributed over the three supersites are given in Table 2. (Ner the whole study area ramfall averaged $513 \mathrm{~mm}$, only marginally below the 1950 1989 average of $550 \mathrm{~mm}$ (Taupin el al., 1993) (Figure 8). Rainfall at the three sites during the IOP is given in Table 4. No rain fell at the sites after 20 September except for $2.3 \mathrm{~mm}$ on 3 October at the west central site. Thus the HAPEX-Sahel achieved one of its major aims which was to make measurements over a wide. range of rainfill conditions.

The meteorological conditions cluring the first $y$ months of 1992 at the East Central site are given in Goutorbe et al. (199:3).

The vegetation deselopment in 1992 was close to the average for the past 12 years. The Nomalised Difference Vegetation Index (NDVI) (Justice 1986) calculated using the Colobal Area Coverage (GAC) data From the Adranced lery High Resolution Radiometer (AVIRRR) carried on the NOAA meteorological, polarorbiting satellite for the four $50 \times 50 \mathrm{~km}$ cuadrants of the $1^{\circ} \times 1^{\circ}$ region (Firure 9) shows that, although lyge did not reach the same peak walues as in 1981, 1983. and 1988 , it nevertheless was similar to the other wars with the exception ol the severe drought year of ighot. One contrast of 1992 with the aremge yen was the marked delaty in the start of the growing season at the central sites as opposed to the southern site (see Fiermi10). The expected north-south gradient of increasing 

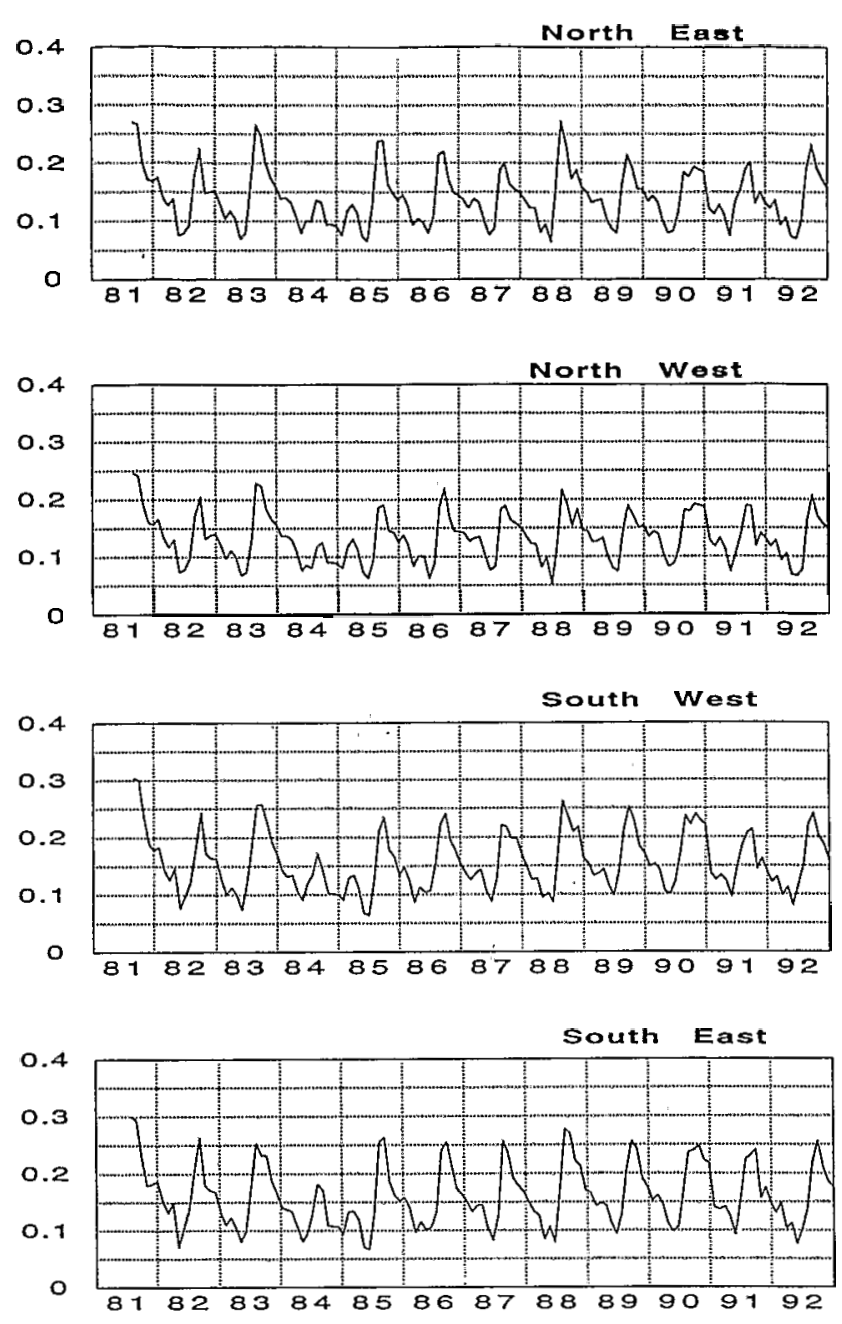

Figure 9. Monthly mean normalized difference vegetation indices (NDVI) for the four quadrants of the HAPEX-Sahel $1^{\circ} \times 1^{\circ}$ square, 1981-1992. NDVI calculated from NOAA Advanced Very High Resolution Radiometer (AVHRR) atsatellite radiances using global area coverage (GAC) data.

vegetation is evident with higher values in the growing season in the southern quadrants. The NDVI in the southern site increased from June and remained above 0.2 for 3 months. The East Central site NDVI increased 1 month later and the West Central a month later again, in August. In both central sites the NDVI was above 0.2 for only 2 months. At Danguey Gorou the NDVI declined sooner than at the other sites and was above 0.2 for only about 6 weeks.

Outside the tiger bush areas, the first significant increase in NDVI is caused by leaf canopy development by Guiera senegalensis, the shrub that forms most of the bush component of the fallow in all of the $1^{\circ} \times 1^{\circ}$ region. In the west central site, the herb layer in the fallow developed as much as 2 months later, at about the same time as millet emerged (Figure 9). The herb layer was initiated by dicotyledonous plants and followed by the grasses. The leaf area indices for the bush

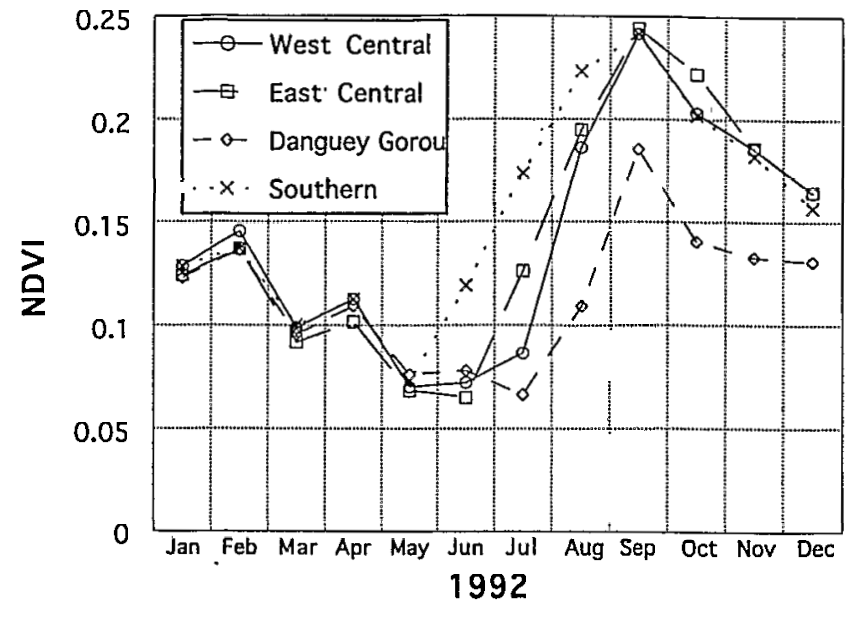

Figure 10. Monthly normalized difference vegetation indices (NDVI) for the three supersites and the Danguey Gorou ancillary site in 1992. NDVI calculated from NOAA Advanced Very High Resolution Radiometer (AVHRR) atsatellite radiances using global area coverage (GAC) data.

component of the fallow bush-grassland, a grassland, and the millet crop at the west central site are shown in Figure 11. The dry period in June caused the millet crop in most fields sown in May to fail except in the south west of the $1^{\circ} \times 1^{\circ}$ square. Fields elsewhere were resown, sometimes more than once. In the southern site millet was harvested between 10 and 15 September but not until about 10 October in the central sites.

Soil moisture storage reached a maximum in late August and generally decreased from then on, with fluctuations following rainfall (Goutorbe et al., 1993). Surface runoff and evaporation account for significant

Figure 11. Leaf area indices (LAI) of the herb and bush components of the fallow bush-grassland, the millet, and the grassland subsites at the West Central supersite during the 1992 season. Lines are fitted values, points indicate observations. Solid line, fallow total; dot-and-dashed line and open circles, fallow herbs; short dashes and open diamonds, fallow bushes; short dashes and closed triangles, millet; long dashes and closed diamonds, grassland.

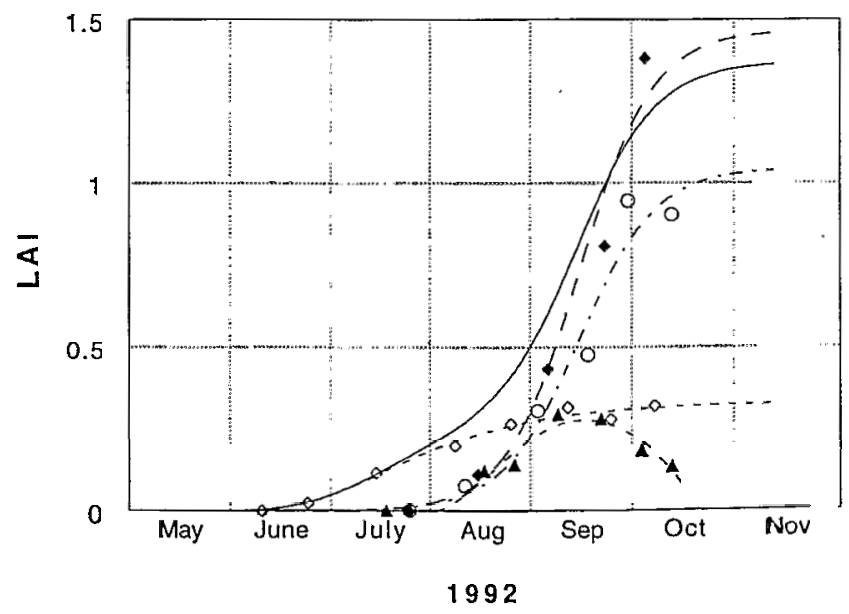


amounts of water immediately following rainfall but, after the last rainfall, the rates of soil moisture depletion seem to reflect differences in transpiration on the sites (Wallace et al., 1993). The tiger bush site behaved quite differently from the sandy sites as may be expected because of its very different soil. The total stored moisture seems to have been higher than the sandy soils. The bare areas between vegetation stripes showed little fluctuation in soil moisture. Rates of water loss exceeded the probable evaporation and so it is possible that some drainage took place through the laterite layers.

Early in the growing season latent heat fluxes were determined largely by the soil evaporation after rain. At this time rainfall events were widely separated in time and the soil surface dried quickly. Later the frequency of rain increased and the soil remained wetter for longer periods. Still later in the season plant transpiration added significantly to the latent heat fluxes. The temporal trend in Bowen ratios is shown in Goutorbe et al. (1993). Values approaching 2 occurred in early August and declined steadily to a minimum of 0.2 in midSeptember. By 10 October the Bowen ratio had risen again to 1.0 , indicating that the observations captured the main feature of the annual cycle.

The trend in the late season from latent to sensible heat flux was also indicated in the depth of the atmospheric boundary layer, which grew from an average altitude of $1 \mathrm{~km}$ in the wetter, midpart of the growing season, occasionally to more than $3 \mathrm{~km}$ toward the end of the rainy season when sensible heat dominated the energy flux (Goutorbe et al., 1993).

\section{AIRCRAFT MEASUREMENTS}

Observations were made from aircraft to bridge the gap between ground observations and satellite data. There were two roles for the aircraft; first, acquisition of data over the subsites and supersites to enable the relationships between the ground and airborne scales of measurement to be determined; second, measurements at the scale of the $1^{\circ} \times 1^{\circ}$ square in order to scale the supersite results to the entire study area.

Four aircraft took part in the study, namely the ARAT Fokker 27 operated by the French Institut Geographique National (IGN), the METEO-FRANCE Merlin IV, the NASA C-130 operated by Ames Research Center in the United States of America, and a Piper Saratoga operated by Sudan Interior Mission Air Services in Niger. The scientific instruments carried by each aircraft are shown in Table 3 together with the principal variables that were measured.

Outline technical specifications of the instruments that were flown in HAPEX-Sahel can be found in the Experiment Plan (Goutorbe et al., 1992). The characteristics of most of the sensors that were operated are already documented in the literature, however, PORTOS and POLDER are less well-known and are described briefly here.

The POLDER (Polarization and Directionality of the Earth's Reflectance) instrument is a visible/near infrared radiometer equipped with a rotating wheel allowing it to make sequential measurements at several wavelengths as well as at several polarizations. Its detector is a charged couple device matrix. Consequently, as the aircraft platform travels forward, each target area is measured at different wavelengths, polarizations, and view angles. By flying parallel lines, several sets of viewing angles are collected. The measurements are used to quantify atmospheric characteristics (particularly the aerosols) and the surface bi-directional reflectance distribution function (BRDF).

PORTOS is a passive microwave instrument with

Table 3. Aircraft, Instruments, and Major Airborne Measurements Made in HAPEX-Sahel

\begin{tabular}{|c|c|c|}
\hline Aircraft & Instruments & Measurements \\
\hline \multicolumn{3}{|l|}{ ARAT Fokker 27} \\
\hline Configuration 1: & POLDER, PORTOS, video. & $\begin{array}{l}\text { Visible and infrared radiances and polarization, } \\
\text { passive microwave. }\end{array}$ \\
\hline Configuration 2: & $\begin{array}{l}\text { Fast response turbulence, temperature, and moisture on } \\
5 \mathrm{~m} \text { nose boom. Mean state sensors for temperature, } \\
\text { dewpoint, and wind. Barnes infrared radiometer for } \\
\mathrm{T}_{\mathrm{s}} \text { long and shortwave up and down. POLDER. }\end{array}$ & $\begin{array}{l}\text { Fluxes of momentum, humidity, and heat. } \\
\text { Aerosols. BRDF. }\end{array}$ \\
\hline $\begin{array}{l}\text { METEO-FRANCE } \\
\text { Merlin IV }\end{array}$ & $\begin{array}{l}\text { Fast response turbulence, temperature, and moisture. } \\
\text { Mean state sensors for temperature, dewpoint. } \\
\text { Barnes infared radiometer. Long and short wave up } \\
\text { and down. }\end{array}$ & $\begin{array}{l}\text { Fluxes of momentum, humidity and heat. } \\
\text { Irradiance in visible and near infrared. }\end{array}$ \\
\hline NASA C -130 & $\begin{array}{l}\text { NS001 TM simulator, ASAS, TIMS, PBMR, } 37 \mathrm{GHz} \\
\text { radiometer, ATSP, Metric camera, laser profiler. }\end{array}$ & $\begin{array}{l}\text { Visible and near infrared radiance images, } \\
\text { thermal emission images, L-band emission } \\
\text { (soil moisture), } 37 \mathrm{GHz} \text { passive microwave } \\
\text { emission, atmospheric transmission, aerial } \\
\text { photography, surface roughness. }\end{array}$ \\
\hline $\begin{array}{l}\text { SIMAIR Piper } \\
\text { Saratoga }\end{array}$ & $\begin{array}{l}\text { Nadir and } 35^{\circ} \text { looking visible, near infrared and infrared } \\
\text { radiometers, video, } 35 \mathrm{~mm} \text { camera. }\end{array}$ & $\begin{array}{l}\text { Visible, near and middle infrared radiances at two } \\
\text { angles, video and color photography. }\end{array}$ \\
\hline
\end{tabular}


5 , dual-polarized frequencies $(5,10.7,23.8,36.5,90$ $\mathrm{GHz}$ ). The instrument resolution is linked to its midpower beam $\left(11^{\circ}\right)$. Only one beam is acquired but its incidence angle can be chosen between 0 and $50^{\circ}$. The range of frequencies available corresponds to that of the Multichannel Imaging Microwave Radiometer (MIMR) that is to be flown on the EOS-pm space platform as well as on the European METOP platform. Together with measurements made with the PBMR instrument on the C-130 aircraft, PORTOS data should allow retrieval of such variables as surface soil moisture, biomass of vegetation, surface roughness, atmospheric integrated water content, and surface equivalent temperature.

The aircraft program consisted of over 20 flight plans, several of which used more than one aircraft, mostly with coordinated balloon ascents. The program was designed. before the experiment and a set of agreed flight plans were specified. In evening meetings the set of flight plans to be operated the next day were selected. The schedule of flying is shown in Table 4.

The flux measurements made by the METEOFRANCE Merlin IV involved measurement of variations in surface sensible and latent heat fluxes within the $1^{\circ} \times 1^{\circ}$ square, assessment of the importance of big eddies in the boundary layer on turbulent fluxes, which are thought to affect upward transport of heat, water vapor, and momentum in the atmosphere above $100 \mathrm{~m}$, measurements of the north-south flux gradient, and measurement of the integrated fluxes for areas of 500 $\mathrm{km}^{2}$. The effects of recent rainfall on fluxes were studied in conjunction with surface moisture measured by the microwave sensors on the CI30 and ARAT.

The Fokker 27 (ARAT) operated as a remote sensing platform during the first month of the IOP (23 August18 September) with PORTOS, POLDER, and a video camera. Although POLDER had already been flown in a few specialized, mainly ocean campaigns, this deployment was the first for PORTOS on an aircraft platform. POLDER flights were at an altitude of $5100 \mathrm{~m}$ above ground level (AGL) and consisted of 5 or 7 parallel lines in the solar principal plane and a complementary line perpendicular to the principal plane. The patterns were centered on subsites and were performed over all three supersites. POLDER missions were organized so as to sample the seasonal vegetation cycle and the range of atmospheric conditions, particularly the aerosol loading. Flights were supported by atmospheric and vegetation measurements, principally in the central west supersite. During all POLDER flights, PORTOS was operated in a nadir viewing mode.

PORTOS missions were flown at an altitude of 900 $m$ AGL so that the size of a footprint corresponded approximately to the area sampled by the flux instruments mounted on towers. Because PORTOS is only a profiler, mapping was performed by flying a series of parallel lines separated by the length of a footprint
(3dB). Most of the flights were performed with a fixed incidence angle of $45^{\circ}$. The three supersites as well as Danguey Gorou were covered several times during the deployment so as to sample the seasonal drying sequence. On one occasion a subset of the East and West central sites ( $1 \mathrm{~km}$ wide) was covered with several viewing angles. Calibration was carried out by taking measurements over the Niger river and on the ground with liquid nitrogen and hot Eccosorb. The MARMOTTE ground radiometer was used for intercalibration.

Whenever possible, PORTOS and PBMR were operated together on their respective aircraft platforms to obtain, as close as possible, synchronous data. Flights were arranged taking into account the field reports of soil moisture changes so as to sample the full cycle of wet to dry soils. On one occasion, a flight took place only minutes after the end of a storm on the southern supersite. Flights were supported by extensive soil moisture measurements and ground measurements of brightness temperature (infrared and microwaves at $4.3 \mathrm{GHz}$ ), coupled with routine measurements of the vegetation and surface fluxes. On several occasions a PBMR and a PORTOS flight occurred within hours of each other, providing microwave measurements at two different scales and with different penetration depths into the soil.

During the second phase of the campaign (29 September-8 October), after a week's break to reconfigure the aircraft, the ARAT operated as a flux measurement platform in conjunction with the Merlin. For each flight one or more radiosoundings were performed in addition to the routine soundings at the southern supersite and Hamdallay. POLDER remained on the ARAT and was used in several missions to observe aerosols high in the atmosphere.

The C- 130 was used to make measurements with all instruments at $1660 \mathrm{~m}$ AGL along four north-south transects of the $1^{\circ} \times 1^{\circ}$ square, spaced between $2^{\circ}$ and $3^{\circ} \mathrm{E}$. Over the southern and combined east and west central supersite, flights at approximately $300 \mathrm{~m}$ were made in order to achieve a spatial resolution of the PBMR similar to the size of the subsites for validation of the airborne remote sensing measurements of surface conditions. Optical measurements of the supersites were made at $5000 \mathrm{~m} \mathrm{AGL}$, where there is less turbulence, in order to achieve better platform stability. The laser profiler was flown at $250 \mathrm{~m}$ AGL. During clear sky conditions optical and thermal missions were given first priority as microwave measurements do not require clear skies. The Zeiss metric cameras were used extensively to provide color and false color infrared stereo aerial photography of the supersites.

The Piper Saratoga was used to carry a lightweight package of instruments that provided nadir and $30^{\circ}$ views in a range of bands from visible to thermal, together with photographs and video. By using a local 


\begin{tabular}{|c|c|c|c|c|c|c|c|c|c|c|c|c|c|c|c|}
\hline \multirow[b]{2}{*}{ Date } & \multicolumn{6}{|c|}{ Weather conditions } & \multicolumn{2}{|c|}{$A R A T$} & \multicolumn{4}{|c|}{$\begin{array}{l}\text { C130 } \\
\text { (NSO01 and TIMS at all times) }\end{array}$} & \multirow[b]{2}{*}{ Merlin + } & \multirow[b]{2}{*}{ Piper } & \multirow[b]{2}{*}{$\begin{array}{l}\text { ARAT+ } \\
\text { Fluxes }\end{array}$} \\
\hline & $\begin{array}{c}\text { Soil } \\
\text { Moisture }\end{array}$ & $\begin{array}{l}\text { Cloud } \\
\text { Octats }\end{array}$ & $\underset{W}{R a i n f a}$ & $\begin{array}{c}\text { (EPS } \\
S\end{array}$ & T) ${ }_{E}^{m m}$ & $\begin{array}{l}\text { Opacity } \\
450 \mathrm{~nm}\end{array}$ & Pottos & Polder & ASAS & $\begin{array}{l}\text { ATSP } \\
\text { Photo }\end{array}$ & $\begin{array}{c}\text { PBMR } \\
\text { Low level }\end{array}$ & $\begin{array}{c}\text { Long } \\
\text { transect }\end{array}$ & & & \\
\hline 41 & ২. & & . & . & . & & & & & & & & mivitis & 3. & \\
\hline 22 & & & 1 & 1 & 8 & & & & & & & & & & \\
\hline .23 & & $5 / 8$ & 0 & 0 & 0 & & $E+R$ & $W^{*}$ & & & & * & MIA & & \\
\hline 24 & 15.5 & & 12.4 & 0.5 & 7 & 0.3 & $E+W+R$ & $\mathrm{~W}$ & & & & $\mathrm{LT}$ & M1A & A & \\
\hline 25 & 16 & & 9.9 & 5.9 & 23.4 & . & & & & & EW & & & & \\
\hline 26 & 19.3 & $0 / 8$ & 0 & 0 & 0 & 0.5 & $A+R$ & & & & EW & & & & \\
\hline 27 & & & 3.5 & 13.9 & 2 & & & & & & & & & & \\
\hline 28 & & cloudy & 32.1 & 17.4 & 29.8 & & & & & & & & M2A & & \\
\hline 29 & 22.8 & cloudy & 23.2 & 21.3 & 17.9 & & & & & $*$ & & LT & M1B & & \\
\hline 30 & & $O C$ & 36.6 & 34.4 & 33.8 & & & & & & & & & & \\
\hline 31 & 18.2 & $\mathrm{BK}$ & $0-33$ & 0.5 & 0 & & & & & & & & $\mathrm{M} 2 \mathrm{~B}$ & & \\
\hline $1 / 9$ & 16.5 & SC $1 / 8$ & 0 & 0 & 0 & $0.5-0.8$ & $A+N+R$ & $W^{*}$ & EW & & & & M2A & $A+N$ & \\
\hline 2 & 14.5 & $6 / 8$ & 0 & 0 & 0 & & $A+R$ & & & & $A$ & & M2B & & \\
\hline \% & . & $1 \%$ & 8. & 6 & $11 \%$ & 6. & 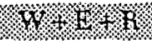 & $17 \%$ & x. & & & & & $1 \%$ & \\
\hline 4 & 12.8 & cloudy & 0 & 0 & 0 & & & & & & A (laser) & & M2A & & \\
\hline 5 & & & 0 & 0 & 0 & 0.4 & & & & & & & M2B & & \\
\hline 6 & 8 & (10)14. & $6 \%$ & 8 & 20 & \% & 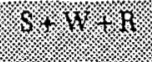 & $6 \% 1 \%$ & & proto & & 1.1 & $\sqrt{1}$ & & \\
\hline 7 & & & 0 & 0 & 0 & & CG & & $\mathrm{E}^{*}$ & & & & & & \\
\hline 8 & 16.4 & & 0 & 0 & 0 & 0.5 & & & $E+W$ & & & & & & \\
\hline 9 & 13.5 & & 0 & 0 & 0 & $0.6-0.7$ & $\mathrm{NA}$ & NA & $S+W$ & & & & M2B & & \\
\hline 10 & 13.6 & cloudy am & 3 & 20.4 & 0 & & NA & NA & $\mathrm{LT}^{*}$ & & & & M2A & $N+W$ & \\
\hline 11 & & $\sim$ clear & 8 & 40.3 & 23.5 & 0.4 & $\mathrm{NA}$ & $\mathrm{NA}$ & & & & & & $E+W^{*}$ & \\
\hline 112 & 10\% & 160 & x. & . & \% & & 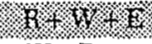 & & & & 1/risse & & x/ & ") & ২: \\
\hline 13 & 16.8 & clean pm & 0 & 0 & 0 & $0.4-0.5$ & $W+R$ & $W$ & $W+E$ & photos & & & M2B & & \\
\hline 14 & & cloudy & 14.8 & 22.9 & 19.4 & & & & & & & & & & \\
\hline 15 & 21.8 & OC & 1.5 & 1.5 & 5 & & & & & & & & & & \\
\hline 16 & 19.9 & cloudy & 8.5 & 0 & 0 & & GC & & & & & & & & \\
\hline $1 \%$ & 41 & (2) & 6. & \% & 10 & $6.5 \%$ & $17 \% 1 \times-17$ & W & 1. & : & 1. & $1 \%$ & $4 / 16$. & . $1 .+1$ & 1. - . \\
\hline 18 & & & 0 & 0.5 & 0 & & GC & & & & & & $\mathrm{M1A}$ & & \\
\hline 19 & 13.8 & & 0 & 0 & 0 & & & & & & & & M2A & & \\
\hline 20 & & & 0.5 & 0 & 0.5 & & & & & & & & & & \\
\hline
\end{tabular}


Table 4. (continued)

\begin{tabular}{|c|c|c|c|c|c|c|c|c|c|c|c|c|c|c|c|}
\hline \multirow[b]{2}{*}{ Date } & \multicolumn{6}{|c|}{ Weather conditions } & \multicolumn{2}{|c|}{ ARAT } & \multicolumn{4}{|c|}{$\begin{array}{c}\text { C130 } \\
\text { (NS001 and TIMS at all times) }\end{array}$} & \multirow[b]{2}{*}{ Merlin +} & \multirow[b]{2}{*}{ Piper } & \multirow[b]{2}{*}{$\begin{array}{l}\text { ARAT+ } \\
\text { Fluxes }\end{array}$} \\
\hline & $\begin{array}{c}\text { Soil } \\
\text { Moisture }\end{array}$ & $\begin{array}{l}\text { Cloud } \\
\text { Octats }\end{array}$ & $\begin{array}{r}\text { Rain } \\
W\end{array}$ & $\begin{array}{c}(E P \\
S\end{array}$ & T) $\underset{E}{m m}$ & $\begin{array}{l}\text { Opacity } \\
450 \mathrm{~nm}\end{array}$ & Portos & Polder & $A S A S$ & $\begin{array}{l}\text { ATSP } \\
\text { Photo }\end{array}$ & $\begin{array}{c}\text { PBMR } \\
\text { Low level }\end{array}$ & $\begin{array}{c}\text { Long } \\
\text { transect }\end{array}$ & & & \\
\hline 21 & & & 0 & 0 & 0 & & & & & & & & & & \\
\hline 22 & & & 0 & 0 & 0 & $0.5-0.6$ & & & & & & & & & \\
\hline 23 & & & 0 & 0 & 0 & & & & & & & & & & \\
\hline 24 & & & 0 & 0 & 0 & & & & & & & & & & M2A \\
\hline 45 & & & 6 & \%) & 6 & $0 \% .0 \%$ & & & & & & & 14. & & 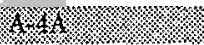 \\
\hline 26 & & & 0 & 0 & 0 & 0.8 & & & & & & & M4B & A & $A-4 B$ \\
\hline 27 & & & 0 & 0 & 0 & 0.7 & & & & & & & & & \\
\hline 28 & & & 0 & 0 & 0 & $0.9-0.7$ & & & & & & & $\mathrm{M} 6 \mathrm{~A}$ & & A6A \\
\hline 29 & & & 0 & 0 & 0 & $1.35-0.7$ & & W & & & & & M2B & & $\mathrm{A} 6 \mathrm{~B}$ \\
\hline 30 & & & 0 & 0 & 0 & & & & & & & & M5 & & A5 \\
\hline $1 / 10$ & & & 0 & 0 & 0 & 1.25 & & & & & & & & & \\
\hline 2 & & & 0 & 0 & 0 & 0.8 & & W & & & & & M2B & & \\
\hline 2. & \% & 举 & 22.8 & \% & 0 & $0 \%$ \% & & & & ;. & \%: & 3 & M2 \% & ২. & 1". \\
\hline 4 & & & 0 & 0 & 0 & 0.6 & & W & & & & & & & \\
\hline 5 & & & 0 & 0 & 0 & & & & & & & & $\begin{array}{l}\text { Merlin/ARAT } \\
\text { calib. }\end{array}$ & & $\begin{array}{l}\text { Merlin/ARAT } \\
\text { calib. }\end{array}$ \\
\hline 6 & & & 0 & 0 & 0 & & & & & & & & & $\mathrm{~N}$ & \\
\hline 7 & & & 0 & 0 & 0 & 0.4 & & & & & & & M6A & A & A6A \\
\hline 8 & 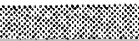 & & (1) & 䋛 & 0.: & 0.4 & & ?: & & & & & 1Hs. & 27 & $1 \%$ \\
\hline 9 & & & 0 & 0 & 0 & & & & & & & & & & M1B \\
\hline 10 & & & 0 & 0 & 0 & & & & & & & & & & A6A \\
\hline 11 & & & 0 & 0 & 0 & & & & & & & & & & \\
\hline 12 & & & 0 & 0 & 0 & & & $\mathrm{~W}^{*}$ & & & & & M5 & & A5 \\
\hline
\end{tabular}

Soil moisture (\% vol, TDR) measured on the East Central Site by A. Chanzy. Opacity measured on the West Central Site by D. Tanré. Golden days shaded.

+ See Experiment Plan for details (Goutorbe et al., 1992)

* Aborted flight

E All Supersites

W West Central Supersite

S Southern Supersite

N Danguey Gorou ancillary (N) site

OC Overcast

GC Ground Calibration

BK Broken Clouds

R Calibration over Niger river 
aircraft it was more easy to make measurements throughout the entire growing season and to take advantage of clear sky conditions whenever they occurred. Measurements were made at $250 \mathrm{~m}$ AGL of all subsites and supersites at approximately 2-week intervals in order to study the growing season from its start until the end of the IOP.

Some important measurement opportunities were provided by the participation of several aircraft-carrying instruments that measured in complementary spectral regions. In planning the flights full use was made of the comparisons between instruments. For example, the PBMR is a nadir-looking instrument with a single frequency $(1.4 \mathrm{GHz}$ ) but a wide swath composed of four sensors, whereas PORTOS has five frequencies (5 to 90 $\mathrm{GHz}$ ) and both polarizations and selectable viewing angles but measures in a narrow profile. There is considerable interest in using the PORTOS higher frequencies and polarizations that are sensitive to vegetation characteristics, such as wet biomass, structure, and surface roughness, to allow for the disturbing effect of vegetation in the PBMR L band data and thereby to improve soil moisture measurement.

Other examples of synergism between aircraft data acquisitions include the use of visible and near infrared reflectance data to quantify vegetation cover and the percentage of bare soil, both for direct use and also to correct microwave measurements; thermal infrared to retrieve the surface temperature and to investigate how well passive microwaves could be used for the same purpose when clouds are present; the POLDER instrument to provide information on the significance of polarization in BRDF to enhance the ASAS data analysis; two flux aircraft to allow the measurement of the vertical divergence of the heat flux and thus the surface flux, which would not have been possible with a single aircraft; and the laser profiler on the C-130, which should yield useful data on surface roughness for comparison with PORTOS microwave data.

Several flights were coordinated with ERS-1 satellite overpasses and were systematically supported by ground measurements of soil moisture, thus HAPEX SAHEL is the first large scale observation program in which passive microwaves were fully investigated for future parameterization and validation of mesoscale and global circulation models.

\section{SATELLITE DATA ACQUISITIONS}

The satellite data acquired during HAPEX-Sahel are shown in Table 5. As anticipated, clear sky conditions were rare during the mid-rainy season and optical and thermal data are therefore sparse for this period. Nevertheless several clear data sets were acquired. This experiment was the first large, integrated field program to benefit from ERS-1 data, including SAR, ATSR, and WINDSCATT. Meteosat and AVHRR data were acquired from receivers in Niamey at AGRHYMET. Landsat TM4 data were acquired by EOSAT using the TDRS data-relay satellites and a special arrangement was made with the EURIMAGE to acquire some TM5 data from ESA's Las Palomas receiving station.

The satellite data acquisition program was designed to optimize the temporal sampling, to cover a range of spatial resolutions from those used in field sampling to the meteorological mesoscale, and to acquire data for all the available frequencies from visible to microwave. The repeat frequency of the satellites used varies from 0.5 hours to 35 days so that temporal interpolations are often necessary, for example when satellite measurements are not available at the same time of the day (eg., ATSR and AVHRR); ground measurements are not synchronous with the satellite overpass; models need data at different times to the satellite overpass; or if

Table 5. Satellite Data Acquired in the HAPEX-II Sahel Experiment

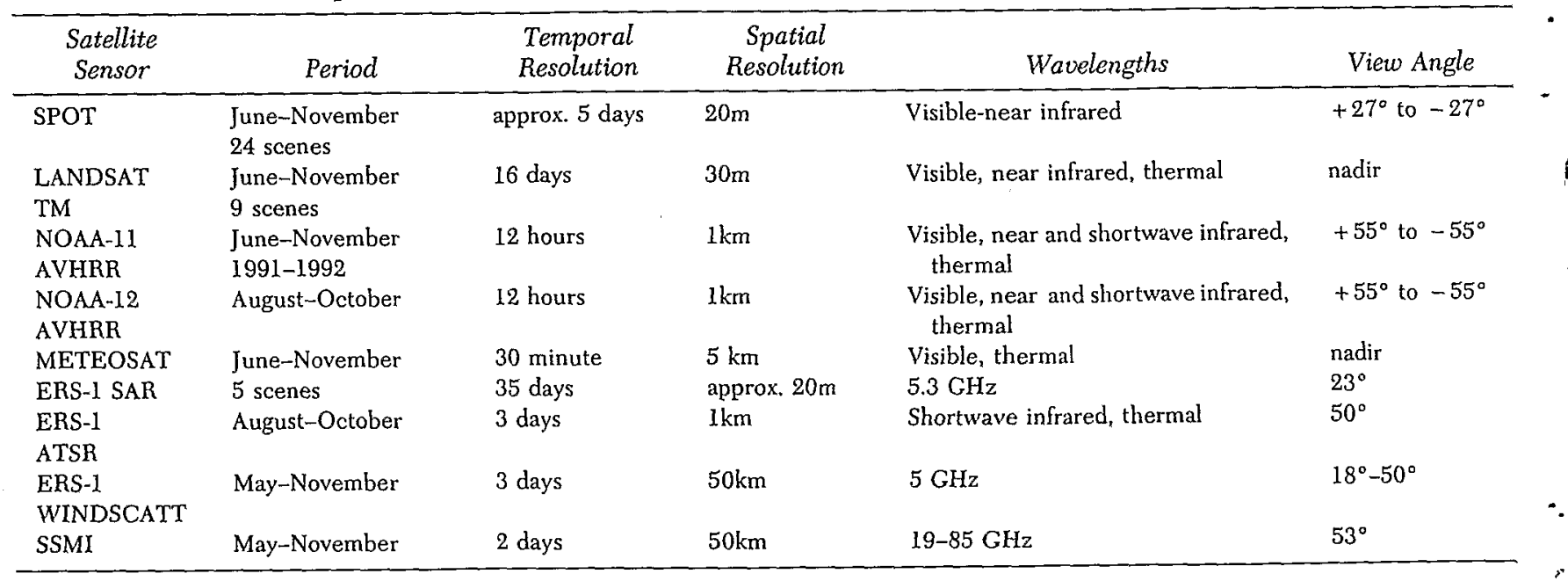


satellite sensors need to be intercalibrated. An example of synergism between sensors is the plan to investigate the use of microwave surface temperature measurements to obtain a continuous surface temperature record even during cloud conditions by relating microwave to thermal infrared measurements in clear sky conditions.

A wide range of spatial resolutions was selected so that upscaling issues could be addressed with measurements performed at several scales from point to meteorological mesoscale grid scales. The full range of the electromagnetic spectrum was utilized with both active and passive measurements from the visible up to $90 \mathrm{GHz}$.

\section{CONTRIBUTED INVESTIGATIONS}

HAPEX-Sahel was a collaborative, interdisciplinary study with contributed investigations on a wide variety of topics, generally directed at addressing the broad aims of the HAPEX program. Over 170 scientists from seven countries in Africa, Europe, and North America participated. In HAPEX, there was no support by contractors for routine measurements requested by the scientific management group. Thus essential measurements needed to achieve the aims of HAPEX that were not proposed at the outset, were identified by the Coordination Committee and its special topic groups, and appropriate teams were requested to add them to their existing program. Much of the HAPEX program therefore depends on formal and informal collaborations between science groups. This has already proved particularly fruitful in initiating interdisciplinary discussions and research.

A list of investigations is given in Table 6. This list is taken from the Experiment Plan (Goutorbe et al., 1992) and includes some investigations that did not materialize as well as omitting some others that were added later. Nevertheless the list does give a reasonable indication of the range of studies undertaken. The studies were organized into four disciplinary groups, each under the leadership of a member of the Coordination Committee. The groups were: Remote Sensing Science, Flux and Vegetation Studies, Meteorology and Mesoscale Studies, and Hydrology and Soil Moisture Studies. Further details can be found in Goutorbe et al. (1992). The allocation of individual projects to disciplinary groups was, inevitably, somewhat arbitrary as most projects could have been placed in two or more groups. Moreover the allocation to groups should not be taken to indicate that interdisciplinary studies were uncommon in HAPEX-Sahel, on the contrary there were many links between different disciplines, especially at the supersite level.

\section{Remote Sensing Science}

Most investigations included under remote sensing science are closely related to specific science investigations that also involve field measurements. Some studies are specifically aimed at developing direct and inverse models to link surface and atmospheric variables with satellite data (remote sensing science) but others are more concerned with using remotely sensed data with appropriate models to study surface processes such as reflectance, the BRDF for different wavelengths, albedo, surface temperature, roughness, soil moisture, canopy type and structure, and also atmospheric aerosol type and loading. Many of the investigations included here explicitly address the appropriate means of scaling measurements from local field sites to the $1^{\circ} \times 1^{\circ}$ square and beyond.

\section{Hydrology and Soil Moisture Studies}

Hydrological studies included an important part of the longer-term studies in HAPEX, some studies having been planned to continue from 1990 to 1993 inclusive. Four scales of study were recognized, the subsite, the hydrologic unit scale (watershed or endoreic unit), the supersite, and the $1^{\circ} \times 1^{\circ}$ square. Within these scales the principal processes of interest were infiltration, runoff, and water fluxes at and below the surface. At the subsite scale the main issues were soil hydrodynamic properties, small scale spatial variation, the relation between surface and profile water content, and the relation between evapotranspiration, groundwater recharge, and soil moisture. At the scale of a single hydrological entity the various hydrological units were characterized and mapped, their hydrodynamic properties were measured including recharge studies from pools and neighboring land units, soil moisture spatial variability was mapped and the water balance was determined. The supersite scale facilitated comparative studies of hydrological entities and studies of spatial integration of entities as well as enabling comparisons with airborne measurements of evapotranspiration. At the $1^{\circ} \times 1^{\circ}$ square scale aquifer recharge was studied along with the water balance. This included use of areal rainfall data from a dense raingauge network and airborne evapotranspiration measurements.

\section{Surface Flux and Vegetation Studies}

The objectives of measurements made by these projects were to quantify and understand the processes involved in the exchange of sensible heat, water, carbon dioxide, and momentum between the surface and the atmosphere. Studies covered a range of scales from individual leaves to the $1^{\circ} \times 1^{\circ}$ square. Measurements at the short time scale were used to detect the response of the vegetation to diurnal and weather changes and to integrate the observations made at a single point in time by remote sensing. Longer time studies were carried out to enable measurements to be made at the growing season scale during which large changes in driving variables occurred and also phenological changes in the vegetation structure and physiology took place. For 
Table 6. Contributed Investigations in HAPEX-Sahel (from Goutorbe et al. 1992).

\begin{tabular}{|c|c|c|}
\hline & Project Description & Principal Investigator \\
\hline \multicolumn{3}{|c|}{ Remote Sensing } \\
\hline RS-01 & $\begin{array}{l}\text { Optimizing satellite data for determination of } \\
\text { agro-climatic surface information in a semiarid } \\
\text { environment }\end{array}$ & $\begin{array}{l}\text { Henrik S. Andersen, Institute of Geography, University of } \\
\text { Copenhagen, Denmark }\end{array}$ \\
\hline RS-02 & $\begin{array}{l}\text { Correlation analysis betwen soil heat/net radiation ratio } \\
\text { and low-high resolution spectral data in non-uniform } \\
\text { landscapes }\end{array}$ & $\begin{array}{l}\text { Wim G. M. Bastiaanssen, Winand Staring Centre (SC-DLO) } \\
\text { Wageningen, the Netherlands }\end{array}$ \\
\hline RS-03 & Energy budget and radiometric studies & $\begin{array}{l}\text { Heiner Billing, Institute fur Atmosphariche Wissenschaffen, Frei } \\
\text { Universitat, Berlin, Germany }\end{array}$ \\
\hline RS-04 & Estimation of spatial variation of soil moisture & Ken Blyth, Institute of Hydrology, UK \\
\hline RS-05 & $\begin{array}{l}\text { Determination of land surface temperature using NOAA } \\
\text { AVHRR data }\end{array}$ & Vicente Caselles, Universitat de Valencia, Spain \\
\hline RS-06 & $\begin{array}{l}\text { Use of passive microwave for estimation of regional scale } \\
\text { evapotranspiration }\end{array}$ & Andre Chanzy, INRA, France \\
\hline RS-07 & Evapotranspiration fluxes & $\begin{array}{l}\text { Zoltan Dunkel, Orszagos Meteorolog-íciai Szolgalat, Kozponti } \\
\text { Meteorologiai Intezet, Hungray }\end{array}$ \\
\hline RS-08 & Spectral reflectance for mineralogy & $\begin{array}{l}\text { G.F. Epema, Dept. of Soil Science and Geology, Wageningen } \\
\text { Agricultural University, Netherlands }\end{array}$ \\
\hline RS-09 & $\begin{array}{l}\text { Biophysical quantities affecting land surface atmosphere } \\
\text { exchanges }\end{array}$ & $\begin{array}{l}\text { Janet Franklin, Dept. of Geography, San Diego State University, } \\
\text { USA }\end{array}$ \\
\hline RS-10 & $\begin{array}{l}\text { Estimation of the surface radiation budget using } \\
\text { multi-look remotely sensed data }\end{array}$ & Robert Gurney, NUTIS, University of Reading, UK \\
\hline RS-11 & $\begin{array}{l}\text { Mapping surface temperature variations with thermal } \\
\text { infrared multispectral scanner (TIMS) data }\end{array}$ & Simon J. Hook, Jet Propulsion Laboratory, USA \\
\hline RS-12 & $\begin{array}{l}\text { Invertible reflectance modeling for semi-arid } \\
\text { environments }\end{array}$ & $\begin{array}{l}\text { Alfredo Huete, Dept. of Soil and Water Science, University of } \\
\text { Arizona, Tucson, USA }\end{array}$ \\
\hline RS-13 & Passive microwave and soil moisture estimation & Yann Kerr, LERTS, France \\
\hline RS-14 & $\begin{array}{l}\text { Establishment of relationships for estimating fluxes by } \\
\text { remote sensing at the regional scale }\end{array}$ & Jean-Pierre Lagouarde, INRA, France \\
\hline RS-15 & Albedo and surface roughness at multiple spatial scales & J.P. Muller, University CollegeLondon, UK \\
\hline RS-16 & $\begin{array}{l}\text { Relationship between rainfall, soil moisture and remotely } \\
\text { sensed vegetation indices }\end{array}$ & $\begin{array}{l}\text { Sharon Nicholson, Dept. of Meteorology, Florida State } \\
\text { University, Tallahassee, USA }\end{array}$ \\
\hline RS-17 & Mapping of lineaments and fracture networks & J.C. Pion, GSTS, Institut de Geologie, France \\
\hline RS-18 & Remote sensing vegetation production in the Sahel & $\begin{array}{l}\text { Stephen D. Prince, Dept. of Geography, University of Maryland } \\
\text { at College Park, USA }\end{array}$ \\
\hline RS-19 & Remote sensing of vegetation biophysical properties & Jean-Louis Roujean, CNRM, France \\
\hline RS-20 & Passive remote sensing of surface soil moisture and & Tom Schmugge, USDA BARC, Maryland, USA \\
\hline
\end{tabular}

RS-21 Studies of microwave emission characteristics of soil-canopy system

RS-22 Measurement of aerosol optical properties and correction of remotely sensed data during HAPEX-Sahel

RS-23 Estimation of spatial variation of evaporation

RS-24 Measurement and analysis of surface temperature by IRT remote sensing

RS-25 Atmospheric measurments, aerosol sampling and BRDF measurements

RS-26 Estimating absorbed PAR and hemispheric reflectance using an airborne pointable imaging spectrometer (ASAS)

Hydrology and Soil Moisture

HS-01 Ground water recharge study over the Sadore Area

HS-02 Sediment fluxes

HS-03 Variations of soil moisture and other surface parameters using airborne multispectral observations

HS-04 Soil moisture measurements at the Southern site

HS-05 Modeling and visualization of soil mositure redistribution

HS-06 Surface hydrology: water balance of small active catchments, and pools

Anatoli Schutko, USSR Academy of Sciences, Moscow, Russia

Michael Spanner, NASA Ames Research Center, USA

John B. Stewart, Institute of Hydrology, UK

Marc-Phillippe Stoll, LSIT-GSTS, France

D. Tanre, LOA, University of Lille, France

Charles Walthall, Dept. of Geography, University of Maryland at College Park, USA

J. Bromley, Institute of Hydrology, UK

A. Chappell, University College, London ${ }_{x}$ UK

Bhaskar J. Choudhury, NASA GSFC, USA

J.D. Cooper, Institute of Hydrology, UK

R. Cuenca, Oregon State University, USA

M. Esteves, ORSTOM, Niger 
HS-07 Soil surface moisture content for remote sensing

HS-08 Derivation of effective soil hydraulic parameters using multitemporal passive microwave data

HS-09 Rainfall estimation and modeling

HS-10 Soil mapping and classification

HS-11 Aquifer recharge; left bank of the Niger river

HS-12 Water energy balance in arid/semi-arid regions

HS-13 Soil properties and their spatial variability

HS-14 Surface hydrology and erosion processes

HS-15 Characterization of surface and soil conditions at the small watershed

HS-16 Soil water balance monitoring at the Central site

HS-17 Short range variability in water balance and millet growth at the Southern site

Surface Flux and Vegetation

FV-01 Water use by vegetation in the Sahel

FV-02 Eddy correlation measurements at the Central East supersite

FV-03 Energy budget measurements over millet and grassland

FV-04 Micro meteorological measurements at the Central West Site

FV-05 . Stable isotope studies of soil-plant-atmosphere interaction

FV-06 Spatial variability of surface heat fluxes

FV-07 Mapping soil hydrology parameters with remote sensing

FV-08 Mapping of land surface types

FV-10 Mapping vegetation, landscape and heterogeneity

FV-Il The carbon dioxide exchanges of Sahelian vegetation in HAPEX-Sahel

FV-12 Energy, water and $\mathrm{CO}_{2}$ fluxes of natural vegetation: measurement and upscale modeling

FV-13 Energy and water balance of the Central Site

FV-14 Agroclimatology studies in millet

FV-15 Evapotranspiration and heat fluxes in the Fandou Beri area

FV-16 Evapotranspiration and heat fluxes in the Danguey Gorou area

FV-17 Transfer characteristics for sparse canopies

Meteorology and Mesoscale Studies

MET-01 Experimental mesocale meteorology for HAPEX-Sahel

MET-02 Mesocale modeling of the HAPEX-Sahel data set

MET-03 Climatology of the HAPEX-Sahel area

MET-04 African climate and vegetation studies related to the HAPEX-Sahel experiment

MET-05 Airborne fluxes over the HAPEX-Sahel square

MET-06 Satellite studies of precipiatation and evapotranspiration feedback processes on the radiation budget within HAPEX

MET-07 Satellite rainfall estimation and vegetation dynamics in the HAPEX-Sahel Experiment
D. Hoekman, Dept. of Water Resources, Agricultural University, Wageningen, Netherlands

Pavel Kabat, Winand Staring Centre (SC-DLO), Wageningen, Netherlands

T. Lebel, ORSTOM, Niger

D. Legger, Dept. of Soil Science and Geology, Agricultural University of Wageningen, Netherlands

F. Lenoir, ORSTOM, Niger

S. Sorooshian, Dept. of Hydrology and Water Balance, University of Arizona, USA

J.N.M. Stricker, Dept. of Water Resources, Agricultural University of Wageningen, Netherlands

J.N.M. Stricker, Dept. of Water Resources, Agricultural University of Wageningen, Netherlands

M. Valentin, S. Galle, ORSTOM, Niger

M. Vauclin, Institute de Mécanique de Grenoble, Lab. Etude des Transferts en Hydrologie et Environment, Grenoble, France

J. Brouwer, ICRISAT, Niger

Simon J. Allen, Institute of Hydrology, UK

Pierre Bessemoulin, CNRM, France

Hans-Jurgen Bolle, Institut fur Meteorologie, Germany

Henk A.R. de Bruin, Dept. Meteorology, Wageningen

Agricultural University, Netherlands

Jean-Pierre Brunel, ORSTOM, Niger

George Dugdale, Dept. of Meteorology, University of Reading,

UK

G.F. Epema, Department of Soil Science, Wageningen

Agricultural University, Netherlands

Peter Frederiksen, Roskilde University Center, Denmark

J.M. d'Herbes, ORSTOM, Niger

P.G. Jarvis, Institute of Ecology and Resource Management,

University of Edinburgh, UK

P. Kabat, Winand Staring Centre (SC-DLO),

Wageningen, Netherlands

B.A. Monteny, ORSTOM, Niger

M.V.K. Sivakumar, ICRISAT, Niger

Henrik Sфgaard, Institute of Geography, University of Copenhagen, Denmark

Henrik S $\phi g a a r d$, Institute of Geography, University of Copenhagen, Denmark

A. Tuzet, INRA, France

Pierre Bessemoulin, CNRS, France

A.J. Dolman, Winand Staring Centre (SC-DLO), Wageningen, the Netherlands

Alio Maidoukia, DNM, Niger

Sharon Nicholson, Dept. of Meteorology, Florida State

University, USA

Frederique Said, Laboratoire d'Aerologie, University Paul Sabatier, France

Eric A. Smith, Dept. of Meteorology and Supercomputer Computations Research Institute, Florida State University, USA

Wassila Thiao, NOAA/NESDIS/SAL, Washington, DC, USA 
practical reasons the different time scales dictated to some extent the spatial scales of the measurements; high temporal frequency measurements are only possible on single plants or small plots, whereas entire growing season measurements can address more realistic scales for the regional aims of HAPEX. Vegetation mapping was an important requirement for upscaling as the dynamic properties of the fluxes from different landscape components can be expected to be quite different. For example, the large areas of bare soil in millet fields and tiger bush should be a major source of water vapor immediately following rain, but the deeper rooted woody species of the fallow and tiger bush might be expected to prolong evaporation when bare surface soil has dried. Several modeling approaches are being used including soil-vegetation-atmosphere (SVAT) models, energy balance models, and models of primary production forced by field and remotely sensed data. Canopy radiative transfer modeling studies were undertaken in conjunction with remote sensing studies. Special attention was given to spatial variability of the vegetation, especially in millet fields.

\section{Meteorology and Mesoscale Studies}

The fundamental objective of the meteorological studies was to place the HAPEX-Sahel results, which are necessarily limited in space and time, in a climatic and regional perspective. Additional field, sonde, airborne, and satellite measurements were needed to augment the sparse permanent network of measurement sites in the region. Mesoscale meteorological modeling has been shown in studies similar to HAPEX-Sahel to be a potential means of upscaling from the measurement region to the GCM grid cell scale. Field measurements were therefore planned to enable a three-dimensional mesoscale model to be implemented. It is planned to initialize the model using data from the UK Meteorological Office operational global forecast model, which has a grid scale of $100 \mathrm{~km}$. Radiosonde and other data acquired in the field will be used to augment normal inputs to the UK model, which will, in turn, provide the inputs for the 3-D model. The 3-D model depends heavily on data from many other HAPEX projects, such as land surface maps, surface and aircraft fluxes. Sensitivity studies will be undertaken with one- and two-dimensional versions of the 3-D model to determine the effects of such features as the Niger river valley and the Dalol Bosso. The results will be compared with current GCM models that use aggregate descriptions of land cover and other forcing variables.

\section{HAPEX-SAHEL INFORMATION SYSTEM (HSIS)}

The collaborative nature of many investigations in HAPEX-Sahel and the anticipated general interest in the data acquired led to the organization of the HAPEX-
Sahel Information System (HSIS). HSIS is arranged hierarchically and is broadly compatible with the FIFE Information System (FIS) (Strebel et al., 1990). All data are being entered into HSIS in a standardized format and are being released periodically on CD-ROM. After the data sets are submitted, but before release on $\mathrm{CD}$ ROM, the data are accessible from a central computer in the form in which they were submitted. The data files are accompanied by text files containing full details of the methods used to collect and process the data. Compatibility with FIFE and the BOREAS Information System has been an important design criterion. HSIS is based in LERTS, Toulouse, France and is assisted by University of Maryland and FIS in the USA.

Shortly after the field campaign 9 "golden" days were selected when weather conditions were good, most instruments were operative, and when satellite overpasses were expected. The golden days are August 20 and 21; September 3, 6, 12, 17, and 25; and October 3 and 8 . Some supersites have designated additional site golden days for their internal data comparisons. Data for golden days were due to be submitted to HSIS by 15 March 1993. All other data are due by 15 March 1994. The data policy adopted by the Coordination Committee is designed to protect those whose field work continues after the end of the IOP in 1992. The policy allows access to the data for HAPEX-Sahel participants only until 15 March 1995, whereafter individuals authorized by the Coordination Committee may be granted access. The data base becomes public on 15 March 1997. Individual participants are free to share their own data with others at any time. The full data policy is available from HSIS.

\section{OVERVIEW AND APPLICATIONS OF HAPEX-SAHEL RESULTS}

HAPEX-Sahel addressed a very wide range of scientific topics and did so over an unusually large and heterogeneous study area. For this reason the scaling of measurements and relationships between the field measurement sites and the entire $1^{\circ} \times 1^{\circ}$ square is a central concern in the data analysis. Interdisciplinary studies will play an important role in the current and future program of workshops, meetings, and collaborative analyses because it will be necessary in most projects to make use of covariates as well as models that are driven by remotely sensed variables in order to transcend scales. A very wide range of field, aircraft, and satellite measurements are available. The only major missing items were aircraft SAR and scatterometer and ground scatterometer measurements. Consequently, whatever the field of study, any investigator should have access to several sets of relevant aircraft and satellite measurements or derived products. This should prove very useful for scaling and $\bullet$ interdisciplinary studies as well as to promote the use 
of remotely sensed data by communities not previously familiar with remote sensing.

Explanations of the dramatic changes in the climate of the Sahel, from wet in the 1900s, 1930s, 1950s, and 1960 s to dry in the 1910s, 1970s, and 1980s (Figure 4), have invoked a variety of mechanisms. Charney (1975) proposed that reduced albedo, caused by reduced vegetation cover, would have a positive feedback through reduced convective rainfall. Rowell and Blondin (1990), among others, have suggested a positive feedback mechanism operating through reduced soil moisture and Sud and Molod (1988) have considered combinations of albedo and soil moisture. Other positive feedback mechanisms have been proposed by Cunnington and Rowntree (1986). Sea surface temperature changes in the Atlantic and elsewhere are the most commonly invoked direct mechanism responsible for reduced rainfall in the Sahel (Lamb, 1978). Most attempts to identify causative factors have considered one variable at a time, but studies by Xue and Shukla (1993) involved a series of GCM simulations with a fairly comprehensive set of "normal" and "desertified" surface conditions. They concluded that reduced vegetation cover, leaf area index, roughness, and soil depth ("desertification") does produce positive feedback and induces the type of changes that have been observed in West Africa, such as reduced rainfall in the Sahel coupled with increased rainfall further south. Although the Xue and Shukla studies have demonstrated the crucial importance of vegetation in the mechanisms, their conclusions are limited by the lack of realistic data to specify the surface and atmospheric conditions for the region as a whole. It is anticipated that HAPEX-Sahel has now corrected the data deficiency in many of the fields discussed above, not only for GCMs but also for many other types of study.

A characteristic feature of the Sahel that is not found in the regions studied in previous measurement campaigns is the intense spatial and temporal variation of atmospheric and surface variables. This has required a somewhat different measurement strategy from earlier studies of this type. In particular it was important to maintain measurements over an 8-week intensive period to sample the seasonal changes and have a reasonable chance to capture infrequent events such as rainfall followed by a drying phase. Fortunately HAPEX-Sahel was successful in capturing several wetting cycles. Moreover the 1992 season was average for the last decade, as is shown by the satellite data (Figure 9). In the spatial domain some difficulty was caused by the landscape of the valleys that form the largest cover class. The fine-grained patchwork of cover types in the heavily cultivated valleys made it difficult to select large, uniform units for the subsites. In most cases sufficiently large subsites were located but any more extreme form of landscape texture would demand a two-scale measurement design on the ground surface, with nested measurements of the landscape and landscape components.

Some early results of HAPEX-Sahel are given in Goutorbe et al. (1993). More detailed information on the southern supersite is given in Wallace et al. (1993) and for the east central supersite in Monteny (1993).

HAPEX-Sahel was a severe test of instruments, personnel, and communications. In the event few serious problems occurred and no major measurement activity was prevented by instrument failure or logistic support. Apparently simple resources such as vehicles were the most troublesome and costly necessities. An unexpected need that was satisfied by the NASA C-130 aircraft was for aerial photography owing to the lack of recent maps. Good liaison with and cooperation of the Government of Niger were key features in the success of HAPEX-Sahel.

The execution of a collaborative, international experiment such as this requires the dedicated efforts of a great many people, many of whom cannot be named here. We wish to thank our collaborators in Niger at DMN, DRE, University of Niamey, INRAN, Aéroport de Niamey Authority, Groupement Aerien National, AGRHYMET, ICRISAT, and ACMAD. Financial support for HAPEX-Sahel was obtained from ORSTOM, Météo France, INSU/CNRS, Ministère de la Recherche et de l'Espace, Ministère de l'Environment; Ministère de l'Education Nationale et de la Culture, and the Conseil Régional Midi Pyréneés (all of France), ODA, NERC and the NERC TIGER Programme, JEP (all of the United Kingdom), NASA (USA), the European Community (grant No. EEC N-EPOC-CT90-0024-C(DSCN) and Environment EV5V-CT91-0033), and from several national funding agencies of Denmark, the Netherlands, and Germany. The first author acknowledges NASA grant NAG 5-1471.

\section{REFERENCES}

Ambouta, K. (1984), Contribution à l'édaphologie de la brousse tigré de l'ouest Nigérien. Thesis presented to the University of Nancy I for the degree of Docteur-Ingénieur, 29 October 1984.

André, J.-C., Goutorbe, J.-P., Perrier, A., et al. (1988), Evaporation over land surfaces: first results from HAPEXMOBILHY special observing period. Annales Geophysicae 6:477-492.

Bolle, H. J., André, J.-C., Arrue, J. L., et al. (1993), European Field Experiment in a Desertification-threatened Area, Annales Geophysicae 11:173-189.

Casenave, A., and Valentin, C. (1989), Les Etats de Surface de la Zone Sahélienne, influence sur L'Infiltration, ORSTOM, Paris, pp. 229.

Charney, J. G. (1975), Dynamics of deserts and droughts in the Sahel, Q. J. Royal Meteor. Soc. 101:193-102.

Cunnington, W. M., and Rowntree, P. R. (1986), Simulations of the Saharan atmosphere dependence on moisture and albedo, Q. J. Royal Meteor. Soc. 112:971-999.

Courault, D., d'Herbes, J.-M, Timouk, F., and Valentin, C. (1992), Spatiocarte des états de surface du degré carré de Niamey, ORSTOM, Niamey, Niger. 
Epema, G. F., and Oevelen, P. J. (1993), Monitoring landsurface characteristics in Niger using complementary SPOT and ERS-1 SAR data. In Proceedings of International Symposium: From Optics to Radar-SPOT and ERS Applications, Paris 10-13 May 1993.

Farmer, G. (1989), Rainfall, in The IUCN Sahel Studies 1989 (M. Norton-Griffiths and P. Ryden, Eds.) International Union for Conservation of Nature and Natural Resources, Nairobi, pp. 1-25.

Franke, R. W., and Chasin, B. H. (1992), Seeds of Famine, Rowman and Littlefield Publishers, Lanham, MD.

Goutorbe, J. P., Lebel, T., Tinga, A., et al. (1992), Experiment Plan for HAPEX-Sahel, ORSTOM, Montpellier.

Goutorbe, J. P., Lebel, T., Tinga, A., et al. (1994), HAPEXSAHEL: a large scale study of land-atmosphere interactions in the semi-arid tropics, Annales Geophysicae 12:53-64.

Justice, C. O., Ed. (1986), Special Issue, Int. J. Remote Sens. 7:1383-1622.

Lamb, P. J. (1978), Large scale tropical Atlantic surface circulation patterns associated with Saharan weather anomalies, Tellus, 30:240-251.

Lebel, T., Sauvageot, H., Hoepffner, M., Desbois, M., Guillot, B., and Hubert, P. (1992), Rainfall estimation in the Sahel: The EPSAT-NIGER experiment, Hydrol. Sci. J. 37:201215.

Legger, D. (1993), Soils of the "West Central site" in Niger. Internal report, Wageningen Agricultural University, Department of Soil Science and Geology.

Le Houérou, H., N. (1989), The Grazing Land Ecosystems of the African Sahel, Springer-Verlag, New York.

Leroux, M. (1983), The Climate of Tropical Africa, Champion, Paris.

Monteny, B. A. (1983), HAPEX-Sahel 1992, Campagne de Mesures Supersite Central Est, ORSTOM, Montpellier.

Rowell, D. P., and Blondin, C. (1990), The influence of soil wetness distribution on short range rainfall forecasting in the west African Sahel, Q. J. Royal Meteor. Soc. 116:14711485.

Sellers, P. J., Hall, F. G., Asrar, G., Strebel, D. E., and Murphy,
R. E. (1988), The first ISLSCP field experiment (FIFE), Bull. Am. Meteor. Soc. 69:22-27.

Sivakumar, M. V. K. (1989), Agroclimatic aspects of rainfed agriculture in the Sudano-Sahelian Zone, In Soil, Crop and Water Management in the Sudano-Sahelian Zone, Proceedings of an International Workshop 11-16 January 1987, ICRISAT Sahelian Center, Niamey, Niger, (C. Renard, R. J. Van Den Beldt, and J. F. Parr, Eds.), pp. 17-38.

Strebel, D. E., Newcomer, J. A., Ormsby, J. P., Hall, F. G., and Sellers, P. (1990), The FIFE Information System, IEEE Trans. Geosci. Remote Sens. 28:703-710.

Sud, Y. C., and Molod, A. (1988), A GCM simulation study of the influence of Saharan evapotranspiration and surface albedo anomalies on July circulation and rainfall. Monthly Weather Rev. 116:2388-2400.

Taupin, J. D., Lebel, T., Cazenave, F., et al. (1993), EPSATNIGER Campaign 1992. ORSTOM / DMN, Niamey, Niger, pp. $64+$ appendices.

van den Oever, P. (1989), Population, In The IUCN Sahel Studies 1989 (M. Norton-Griffiths and P. Rydén, Eds.) International Union for Conservation of Nature and Natural Resources, Nairobi, pp. 26-51.

Wallace, J. S., Brouwer, J., Allen, S. J., et al. (1994), The HAPEX-Sahel Southern Supersite Report, Institute of Hydrology, Wallingford (in preparation).

White, F. (1983), The Vegetation of Africa, A Descriptive Memoir to Accompany the UNESCO / AETFAT / UNSO Vegetation Map of Africa. UNESCO, Paris.

White, L. P. (1971), Vegetation stripes on sheet-wash surfaces, J. Ecol. 59:615-622.

Wilding, L. P., and Hossner, L. R. (1989), Causes and effects of acidity in Sahelian soils, In Soil, Crop and Water Management Systems for Rainfed Agriculture in the Sudano-Sahelian Zone, proceedings of an International Workshop, 11-16 Jan 1987, ICRISAT Sahelian Center, Niamey, Niger, ICRISAT, Patancheru, India, pp. 215-227.

Xue, Y., and Shukla, J. (1993), The influence of land surface properties on Sahel climate; Part I - desertification, J. Climate 6:2232-2245. 